\title{
Jerzy Gordziejew
}

Uniwersytet Jagielloński

\section{Wokół genezy administracji lokalnej w Wielkim Księstwie Litewskim: uwagi i propozycje}

\begin{abstract}
Zarys treści
Prezentowany artykuł przybliża genezę administracji lokalnej w Wielkim Księstwie Litewskim i jest przedstawieniem propozycji badawczych. Zgromadzony materiał sygnalizuje złożony charakter uwarunkowań procesu jej kształtowania. Aukcja wojska oraz związane z nią poważne wyzwania budżetowe skutkowały poszukiwaniem skutecznych sposobów realizacji bieżącej polityki państwa. Swoją strukturą organizacyjną komisje porządkowe przypominały model łączący rozwiązania rodzimych urządzeń ustrojowych z cechami nowożytnej organizacji administracji.
\end{abstract}

\begin{abstract}
The article presents both the problem of genesis of the local administration in the Grand Duchy of Lithuania in 1789 and postulates for further research. The archival sources make it possible to reveal the complexity of the process of its establishment. The increased number of troops caused serious strains on the state budget and this led to a search for effective ways of implementing the current state policy. The structures of civil-military commissions of order resembled the model combining a native system of governmental authorities with some features of modern administration.
\end{abstract}

Słowa kluczowe: administracja terenowa, komisje porządkowe cywilno-wojskowe, Wielkie Księstwo Litewskie, Rzeczpospolita, XVIII w.

Keywords: local administration, Civil-Military Commissions, Grand Duchy of Lithuania, Polish-Lithuanian Commonwealth, eighteenth century

Lokalne życie publiczne w dobie nowożytnej jest postrzegane najczęściej przez pryzmat omówienia rozwijających się od kilku stuleci instytucji parlamentaryzmu i samorządu szlacheckiego, co jest całkiem logiczne ze względu na różnorodne przejawy aktywności publicznej szlachty, a także stan dokumentacji źródłowej. Badania nad historią administracji terenowej w Rzeczypospolitej, która swymi początkami sięga końca lat 80 . XVIII w., grzeszą jednak fragmentarycznością. O ile zagadnienie działalności komisji cywilno-wojskowych zostało w pewnym 
stopniu zobrazowane ${ }^{1}$, to geneza tych pierwszych w dziejach Rzeczypospolitej organów zarządu terytorialnego nie doczekała się wnikliwego omówienia. Toteż temat ten prowokuje do postawienia wielu pytań.

W związku z powyższym przemyślenia przedstawione w niniejszym artykule będą oscylować wokół próby ujęcia genezy, czyli uwarunkowań towarzyszących kształtowaniu się administracji terenowej w Wielkim Księstwie Litewskim w okresie od października 1788 do listopada 1789 r.

Jak można sądzić, owego zagadnienia nie można ograniczać jedynie do działalności legislacyjnej oraz oceny ewolucji organów zarządu lokalnego z perspektywy działań odgórnych. Nie negując doniosłości dokonań Sejmu Czteroletniego, poprzestanie na takim stwierdzeniu i sprowadzenie narracji do analizy treściowej konstytucji sejmowej z listopada 1789 r. oznaczałoby ignorowanie kontekstu historycznego, całokształtu warunków i przyczyn, które zadecydowały o powołaniu do życia zrębów administracji terenowej, potraktowanie innych czynników jako podrzędne.

Wśród wątków skłaniających do refleksji byłoby ukazanie głównych trendów osiemnastowiecznej literatury politycznej, uchwycenie stopnia ewentualnych wpływów założeń ówczesnej myśli ustrojowo-administracyjnej na prace ustawodawcze, motywacji działań oraz pobudek, którymi ustawodawcy mogli się

\footnotetext{
${ }^{1}$ Kompleksowe omówienie historiografii problemu przekracza zakres niniejszego szkicu; zob.: W. Kalinka, Sejm Czteroletni, t. 1, cz. 2, wyd. 4, Kraków 1895, s. 642-647; I. Baranowski, Komisje porządkowe (1765-1788), „Rozprawy Akademii Umiejętności Wydziału Historyczno-Filozoficznego", s. II, t. 24, 1907, s. 107-150; T. Korzon, Komisje porzadkowe Cywilno-Wojskowe wojewódzkie i powiatowe w latach 1790-1792, „Ateneum” 7, t. 1, z. 1, 1882, s. 427-455; idem, Wewnętrzne dzieje Polski za Stanisława Augusta (1764-1794), t. 2, Kraków-Warszawa 1897, s. 296-297, 301; t. 5, s. 196-201; A. Zahorski, Centralne instytucje policyjne w Polsce w dobie rozbiorów, Warszawa 1959; T. Srogosz, Ksztaltowanie się nowożytnych lokalnych organów administracyjno-samorządowych na ukraińskich terenach Rzeczypospolitej w drugiej połowie XVIII wieku, „Південний архів” 20, 2005, s. 8-11; idem, Między unifikacją a dualizmem w systemie władz policyjnych u schyłku pierwszej Rzeczypospolitej, w: Spory o państwo w dobie nowożytnej. Między racją stanu a partykularyzmem, red. Z. Anusik, Łódź 2007, s. 243-254; idem, Nowożytne lokalne organy administracyjno-samorzadowe na ukraińskich terenach Rzeczypospolitej w okresie panowania Stanisława Augusta Poniatowskiego, w: Urzędy państwowe, organy samorządowe i kościelne oraz ich kancelarie, red. H. Gmiterek, J. Łosowski, Kraków 2010, s. 197-210; L. Glemža, Lietuvos Didžiosios Kunigaikštystés miestu sajūdis 1789-1792 metais, Kaunas 2010, s. 93-97; J. Gordziejew, Komisje Porzadkowe Cywilno-Wojskowe w Wielkim Księstwie Litewskim w okresie Sejmu Czteroletniego (1789-1792), Kraków 2010; Ю. Гардзееў, Цывільна-вайсковыя парадкавыя камісіі ў Вялікім Княстве Літоўскім у часы Чатырохгадовага сойма (1789-1792), Смаленск 2014; R. Šmigelskytė-Stukienè, E. Brusokas, L. Glemža, R. Jurgaitis, V. Rakutis, Modernios administracijos tapsmas Lietuvoje. Valstybès instituciju raida 1764-1794 metais, Vilnius 2014, s. 534-539; P. Jędrzejewski, Akta Komisji Porządkowych Cywilno-Wojskowych, „Krakowski Rocznik Archiwalny” 9, 2013, s. 129-157; idem, Komisje Porządkowe Cywilno-Wojskowe województwa krakowskiego w dobie Sejmu Wielkiego (1790-1792), Kraków 2016, Uniwersytet Pedagogiczny, mps pracy doktorskiej napisanej pod kier. prof. dr. hab. Franciszka Leśniaka.
} 
kierować i inspirować, a także ich wykształcenia oraz przekonań2. Warto również przyjrzeć się potencjalnym związkom tradycji samorządowej z charakterem podmiotów wykonujących zarząd na szczeblu lokalnym w badanym okresie. Wreszcie nie sposób nie zastanowić się nad czynnikami (zaistniałą sytuacją społeczno-polityczną oraz gospodarczą, wyzwaniami stojącymi przed społeczeństwem), które oddziaływały na ostateczne kształty ustawy powołującej do życia organy administracji terytorialnej.

Podstawę źródłową tego artykułu stanowią diariusze, mowy sejmowe, pamiętniki oraz zachowane inwentarze bibliotek. Można przyjąć, że lepszemu rozpoznaniu tematu ma posłużyć krytyczne ustosunkowanie się do dorobku osiemnastowiecznej myśli ustrojowo-administracyjnej.

\section{Charakter dyskusji sejmowej w październiku 1788 i lutym $1789 \mathrm{r}$.}

Po upływie roku od czasu rozpoczęcia sejmu, 19 listopada 1789 r. uchwalono konstytucję Komisje wojewódzkie i powiatowe w Wielkim Księstwie Litewskim³, na mocy której powołano do życia terenowe ogniwa władzy wykonawczej, określając ich uprawnienia. Adam Lityński, oceniając efekty pracy sejmu, trafnie zauważył, że projekt o komisjach porządkowych „był to w istocie pierwszy liczący się akt prawny sejmu w zakresie pozytywnego tworzenia nowych form władzy"4. Naturalnie można byłoby się ograniczyć do oczywistego stwierdzenia, że przyjęcie tej uchwały poprzedziła burzliwa dyskusja w okresie od października 1788 do listopada 1789 r. Atmosfera sejmowej dysputy akcentującej uwagę na szerokim wachlarzu tematycznym, w tym poszukiwaniach ewentualnych źródeł podatkowych, nie wzbudza wątpliwości $i^{5}$. Ze względu na ramy niniejszych rozważań nie pretendują one do szczegółowego omówienia całokształtu debaty sejmowej, należałoby jednak poczynić próbę ustalenia, w jakim zakresie przedmiotem prac sejmowych była administracja terenowa sensu stricto?

Kierunki dyskusji w początkowym okresie prac Sejmu Czteroletniego były uwarunkowane październikową decyzją o aukcji wojska oraz uchwałą o ustanowieniu

\footnotetext{
${ }^{2}$ M. Drozdowski, Podstawy finansowe działalności państwowej w Polsce w 1764-1793. Działalność budżetowa Sejmu Rzeczypospolitej w czasach panowania Stanisława Augusta Poniatowskiego, Warszawa-Poznań 1975, s. 133.

${ }^{3}$ Komisje wojewódzkie i powiatowe w Wielkim Księstwie Litewskim, w: Volumina legum, t. 9, Kraków 1889 , s. $136-142$.

${ }^{4}$ A. Lityński, Sejmiki ziemskie 1764-1793. Dzieje reformy, Katowice 1988, s. 67; E. Rostworowski, Ostatni król Rzeczypospolitej. Geneza i upadek Konstytucji 3 Maja, Warszawa 1966, s. 172.

${ }^{5}$ Przebieg dyskusji sejmowej został omówiony w pracy Tadeusza Korzona; zob. idem, Wewnętrzne dzieje Polski za Stanisława Augusta (1764-1794), t. 3, Kraków-Warszawa 1897, s. 203-352.
} 


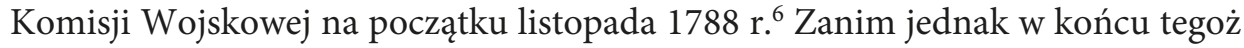
roku doszło do wyłonienia składu Komisji Wojskowej, organem kierującym wojskiem nadal pozostawał Departament Wojskowy Rady Nieustającej ${ }^{7}$. Dyskusja dotycząca obalenia Departamentu nasiliła się 24 października ${ }^{8}$. Zabierając głos, marszałek nadworny koronny Kazimierz Raczyński zapytywał „o urządzenie władzy nad wojskiem Rzeczypospolitej”. Kontynuując wątek, zaznaczał: „żeby żadnej oprócz od Rządu krajowego nie znała dependencji"”. Podobne uwagi o konieczności pozbawienia Departamentu kierownictwa nad wojskiem zostały poczynione 27 października przez posła Ignacego Zakrzewskiego, który zgłosił projekt utworzenia niezależnej do Rady „udzielnej Komisji do zarządzenia wojskiem”10.

Jak można wnioskować, głosy te miały związek z obroną Departamentu Wojskowego, objętego rosyjską gwarancją, przez ambasadora Otto Magnusa von Stackelberga i dążeniem posłów do zmian ustrojowych pozwalających na uniezależnienie się od Rosji ${ }^{11}$. Jak można domniemywać, nie bez znaczenia było i to, że obradujący sejm nie mógł się pogodzić z koniecznością rezygnacji z szerokich uprawnień na rzecz władzy wykonawczej ${ }^{12}$.

$\mathrm{Na}$ tejże dziewiątej sesji sejmowej, 24 października, padły głosy dotyczące ustalenia składu i kompetencji władz wojskowych. Kasztelan czerski Tomasz Ostrowski oraz poseł sandomierski Kazimierz Skorkowski optowali za ich obsadzeniem zarówno oficerami, jak i osobami cywilnymi, określonymi - co ciekawe - przez Ostrowskiego „urzędnikami cywilno-wojskowymi”. Poseł lubelski Stanisław Kostka Potocki z kolei wspomniał o „sądowności cywilno-wojskowej”, Skorkowski zaś o „sądzie cywilno-wojskowym po wszystkich województwach”, którego wprowadzenie tłumaczył względami bezpieczeństwa ${ }^{13}$. Tu warto podkreślić rzucającą się w oczy kombinację słów nawiązującą do nazwy przyszłych instytucji zarządu lokalnego.

Zdaniem Waleriana Kalinki dyskusja tocząca się w pierwszych miesiącach działalności sejmu miała nie do końca przemyślany charakter. Podobne stanowisko

\footnotetext{
${ }^{6} 11$ listopada Stanisław August podkreślił: „Rząd wojska dotąd departamentowi wojskowemu powierzany. My Król za zgodą rzeczypospolitej stanów, odtąd przy komisji wojskowej zostawionym mieć chcemy", zob. Volumina legum..., t. 9, s. 52; Dyaryusz Seymu Ordynaryinego Pod Związkiem Konfederacyi Generalney Oboyga Narodow w Warszawie Rozpoczętego Roku Pańskiego 1788, t. 1, cz. 1-2, Warszawa 1790, tu cz. 2, s. 17, 20; E. Rostworowski, Ostatni król Rzeczypospolitej..., s. 149-150; W. Szczygielski, Debata parlamentarna nad wyłonieniem składu Komisji Wojskowej w grudniu 1788 r., „Przegląd Nauk Historycznych” 10, 2011, nr 1, s. 71-72.

${ }^{7}$ W. Szczygielski, op. cit., s. 72, 79.

${ }^{8}$ L. Ratajczyk, Wojsko i obronność Rzeczypospolitej 1788-1792, Warszawa 1975, s. 67-68.

${ }^{9}$ Dyaryusz Seymu Ordynaryinego..., t. 1, cz. 1, s. 114.

${ }^{10}$ Ibidem, s. 155.

${ }^{11}$ J. Michalski, Zmierzch prokonsulatu Stackelberga, w: Sejm Czteroletni i jego tradycje, red. J. Kowecki, Warszawa 1991, s. 10, 11, 13, 16, 32.

12 R. Łaszewski, Sejm polski w latach 1764-1793, Warszawa-Poznań 1973, s. 22.

${ }^{13}$ Dyaryusz Seymu Ordynaryinego..., t. 1, cz. 1, s. 102, 130.
} 
zajął Leonard Ratajczyk. Koszty utrzymania tak licznej armii przekraczały bowiem możliwości budżetowe państwa. Problem wynikał z braku kadry oficerskiej oraz decyzji o zaciągu szlacheckiej jazdy, nieproporcjonalnego w stosunku do etatu wojska. Dążąc do wyjaśnienia sposobów myślenia posłów, można odwołać się do trafnej obserwacji Tadeusza Korzona, który był zdania, że zrażona uciążliwościami podatkowymi szlachta popierała postulaty powiększenia armii, próbując faworyzować szlachecką kawalerię ${ }^{14}$. Do podobnego poglądu przychylał się Emanuel Rostworowski, który na podstawie zbadanych instrukcji sejmikowych z $1788 \mathrm{r}$. wnioskował, że popularność hasła aukcji wojska, rozbudowy kawalerii oraz lekkiej jazdy znajdowała uzasadnienie w osobistych korzyściach, przede wszystkim „bezrobociu” szlachty, dla której wojsko mogło stanowić podstawę egzystencji1 ${ }^{15}$. Poza tym uzupełnienie szeregów armii według nowych zasad poboru rekruta było nie bez znaczenia dla rozwój gospodarki, gdyż rekrutacja do wojska uderzała w ekonomiczne interesy szlachty ${ }^{16}$. Oczywiście warto się zastanowić, czy powyższe uwagi znajdują źródłowe potwierdzenie.

Rozbudowa armii pociągała za sobą problem nakładania (co właściciele ziemscy odbierali bez entuzjazmu) i sprawnego ściągania podatków ${ }^{17}$. Kwestia ustalenia źródeł oraz zgromadzenia środków niezbędnych dla funkcjonowania wojska zaczęła się wyłaniać $\mathrm{w}$ trakcie październikowych obrad sejmu. 13 października, w dniu złożenia przez Prusy deklaracji o przymierzu, marszałek Stanisław Małachowski nie bez obawy zauważał: „powiększenie sił krajowych innym spełnione być nie może sposobem jak zasileniem dochodów skarbu publicznego, które dla ich utrzymania pewności, czerpane być powinny z stałych i nieodmiennych źródeł dostarczającej liczbie wojska oznaczonej”"18. 16 października poseł kaliski Jan Suchorzewski podkreślał konieczność „ustanowienia władzy nad wojskiem i ułożenia podatków"19.

Za nie mniej wymowny należy uznać nawiązujący do nowego etatu wojska apel kasztelana wiskiego Gabriela Opackiego, który 24 października przedstawił

14 T. Korzon, Wewnętrzne dzieje Polski za Stanisława Augusta (1764-1794), t. 1, Kraków-Warszawa 1897, s. 54; L. Ratajczyk, Wojsko i obronność..., s. 16.

${ }^{15}$ E. Rostworowski, Sprawa aukcji wojska na tle sytuacji politycznej przed Sejmem, Warszawa 1957, s. 110-112, 229-230.

16 T. Korzon, Wewnętrzne dzieje Polski za Stanisława Augusta..., t. 5, 1897, s. 54-55; E. Rostworowski, Sprawa aukcji wojska..., s. 239.

17 W. Kalinka, Sejm Czteroletni, t. 1, cz. 1, Kraków 1895, s. 201-207; E. Rostworowski, Sprawa aukcji wojska..., s. 232-239; idem, Ostatni król Rzeczypospolitej..., s. 163; L. Ratajczyk, Przyczynek do sprawy werbunku i poboru rekrutów na ziemiach polskich w XVIII wieku, „Studia i Materiały do Historii Wojskowości” 15, cz. 1, 1969, s. 64; idem, Wojsko i obronność..., s. 16, 66, 67, 103; W. Szczygielski, op. cit., s. 71.

${ }^{18}$ Dyaryusz Seymu Ordynaryinego..., t. 1, cz. 1, s. 32.

${ }^{19}$ Ibidem, s. 40-41; Zbiór mów i pism niektórych $w$ czasie sejmu stanów skonfederowanych roku 1788 , t. 1, Wilno [b.d.w.], s. 114. 
następną wizję, odbiegającą od treści pozostałych przemówień, które nie były wolne od patosu i euforii: „uchwaliliśmy chcę mówić 100 tysięczne wojsko, ale to nie dosyć. Potrzeba pieniędzy na zaciągnienie, ubranie, uzbrojenie \&c onego. Nasz kraj zdaje się być ubogim, ale patrząc na gust generalny narodu do polepszenia rolnictw, na zakłady różnych krajowych rękodzieł, na chęć wyszukiwania i wydobywania $\mathrm{z}$ wnętrzności ziemi, co może zawierać $\mathrm{w}$ sobie użytecznego i zyskownego [...] nie wątpię o znaleźć się mogących dochodach, ale i to nie dosyć, potrzeba ludzi"20.

Fakt stacjonowania wojska $\mathrm{w}$ różnych zakątkach kraju $\mathrm{z}$ czasem uwidocznił problem przestrzegania prawa przez żołnierzy czy konieczności zażegnania ewentualnych konfliktów pomiędzy żołnierzami a ludnością cywilną. Ustosunkowując się do tej kwestii, 13 października marszałek Stanisław Małachowski nawoływał, by „ten zaś żołnierz aby w przyzwoitej zostawał karności i naprzykrzającym się nie był obywatelowi”21. W podobnym tonie 24 października Kazimierz Raczyński opowiedział się za tym, by władza wojskowa „karność utrzymywała, żeby nią obywatel cywilny uciśniony nie był i żeby wojskiem osoby służbę znające zarządzały”. Raczyński przypuszczał zresztą, że „w składzie tej jurysdykcji osób cywilnych większość zapewnienie bezpieczeństwa dla stanu cywilnego uczyni"22.

$\mathrm{Na}$ osobne potraktowanie zasługują przemyślenia podskarbiego wielkiego litewskiego Stanisława Poniatowskiego z 24 października ${ }^{23}$. Jego wystąpienie można uznać za interesujące $\mathrm{z}$ różnych powodów. W swoim przemówieniu postulował on powołanie władzy „po województwach”, określanej przez niego jako „Komisje Cywilno-Wojskowe”. Nie sposób nie zauważyć, że nazwa komisji była ścisłe skorelowana $\mathrm{z}$ ich ewentualnymi prerogatywami. Miały one bowiem „posiadać [...] drugą cześć tejże władzy wojskowej”. W wyniku powierzenia realizacji zadań z zakresu administracji i sądownictwa nowe magistratury miały przejawiać troskę o bezpieczeństwo mieszkańców ze strony wojska, rozwiązanie „wszelkich kwestii zachodzić mogących między żołnierzem stale konsystujących a miedzy obywatelami tychże województw"24. Do kompetencji komisji należałoby dostarczanie rekruta do jednostki oraz nadzór nad kontraktami furażowymi.

${ }^{20}$ Dyaryusz Seymu Ordynaryinego..., t. 1, cz. 1, s. 120.

${ }^{21}$ Ibidem, s. 36.

22 Ibidem, s. 117.

${ }^{23}$ J. Malec, Polska myśl administracyjna XVIII wieku, Kraków 2008, s. 21.

24 „Komisje Cywilno-Wojskowe tworzyć się mają w kraju, posiadać będą drugą cześć tejże władzy wojskowej, która właściwie cywilną nazwać by się mogła, gdyż gruntuje bezpieczeństwo obywatelów od wojska i zależy na rozwiązywaniu wszelkich kwestii zachodzić mogących między żołnierzem po województwach stale konsystujących a miedzy obywatelami tychże województw, na przystarczniu rekrutów i dozorze, ażeby przyzwoicie użytemi był, na koniec na czynieni prędkiej sprawiedliwości w zawieranych między wojskiem a obywatelami o furaże kontraktach. Już tedy znaczna część władzy, którą miał Departament nad wojskiem, dostałaby się nowej magistraturze, której początkowe utworzenie będzie pamiętną panowania W.K. Mości epoką, bo z niej nastąpić z czasem może ulepszenie i udoskonalenie generalnej kraju całego policji”, Dyaryusz Seymu Ordynaryinego..., t. 1, cz. 1, s. 112; Zbiór mów i pism..., t. 1, s. 177-178. 
Z powyższego można wnioskować, że według posła komisje miały stanowić zręby „władzy wojskowej” szczebla lokalnego, posiadając uprawnienia w zakresie poboru rekruta, uregulowania stosunków pomiędzy ludnością cywilną a wojskiem oraz furażowania. $\mathrm{W}$ tym miejscu nie sposób nie zwrócić uwagi na zbieżność tych postulatów z treścią konstytucji ustanawiającej w listopadzie $1789 \mathrm{r}$. organy władzy wykonawczej w terenie, do kompetencji których należały zadania w zakresie kwaterunku, poboru rekruta, aprowizacji, urządzenia magazynów oraz dostarczania podwód, wydatkowania środków finansowych dla wojska, a także zadośćuczynienia sprawiedliwości polegającej na rozstrzyganiu wzajemnych szkód i krzywd między wojskiem a ludnością cywilną ${ }^{25}$.

Z punktu widzenia dalszych rozważań istotną wydaje się wzmianka podskarbiego o tym, że z tej magistratury „nastąpić z czasem może ulepszenie i udoskonalenie generalnej kraju całego policji”, który tym samym dostrzegał w komisjach podwaliny przyszłego zarządu terenowego. Mimo że do niniejszego pomysłu oraz krystalizacji wizji administracji lokalnej wrócono nieco później, istotnym wydaje się wysunięcie kwestii policji oraz wyraźna perswazyjność wypowiedzi, zawierająca myśl o konieczności gruntownych reform administracji.

$\mathrm{Na}$ jedenastej sesji sejmu 30 października 1788 r. pod rozwagę posłów zgłoszono projekt o Komisji Wojskowej, którego autorzy postulowali ustanowienie sądów cywilno-wojskowych w każdym województwie. Proponowano, by na najbliższych sejmikach gospodarskich szlachta obrała na dwuroczną kadencję „ośmiu obywatelów na sędziów cywilno-wojskowych" z możliwością udziału w posiedzeniach „sztabs lub oberoficer"26. Autorzy projektu wyraźnie nawiązywali do samorządu sejmikowego poprzez ustanowienie "sądu ziemskiego czyli grodzkiego"27.

12 listopada biskup inflancki Józef Kossakowski wniósł propozycję o zastosowaniu zasady proporcjonalności w obsadzeniu składu Komisji Wojskowej: „ażeby równa liczba z Prowincji Litewskiej była zawarowaną". Druga poprawka dotyczyła wyboru wojskowych komisarzy na sejmach „po elekcyi komisarzy skarbowych”28. Z kolei 20 listopada podniesiono kwestię pensji „urzędników cywilno-wojskowych” bądź „cywilno-wojskowych komisarzy”29.

Podczas pierwszej sesji po świętach, która odbyła się 7 stycznia 1789 r. ${ }^{30}$, w sejmie przedstawiono projekt Ustanowienie Komisji Wojewódzkiej, który był powielony oraz rozdany w celu "deliberacji” ${ }^{1}$, co niewątpliwie wskazywało na wagę problemu.

\footnotetext{
${ }^{25}$ Komisje wojewódzkie i powiatowe w Wielkim Księstwie Litewskim..., s. 136-156.

${ }^{26}$ Dyaryusz Seymu Ordynaryinego..., t. 1, cz. 1, s. 204.

${ }^{27}$ Ibidem, s. 207.

${ }^{28}$ Ibidem, cz. 2, s. 60.

${ }^{29}$ Ibidem, s. 114-119.

${ }^{30}$ W. Kalinka, Sejm Czteroletni... (1895), t. 1, cz. 2, s. 531.

${ }^{31}$ Diariusz Sejmu Czteroletniego (sesje 1-71), z drukowanego wydania Jana Pawła Łuszczewskiego, Dyaryusz seymu ordynaryinego pod związkiem Konfederacyi Generalney oboyga narodow
} 
Na następnej sesji, 8 stycznia, poseł lubelski Stanisław Ignacy Wybranowski ze sceptycyzmem ustosunkował się do pomysłu „ciągłej i niezmiennej” dyslokacji jednostki w jednych dobrach, ponieważ - jak tłumaczył - właściciel dóbr, będąc jednocześnie „szefem komendantem”, będzie dbać o własne gospodarstwo, „od ekonomiki y porządku ogólnego wojska dalekiego"32. Kontynuując, wyraził przekonanie, że proponowane rozwiązanie odbiłoby się ujemnie na działalności komisji wojewódzkiej, które „nic albo mało czynna będzie”, dążenie zaś do uzyskania stałego przydziału dyslokacyjnego tłumaczył chęcią właścicieli ziemskich zwrotu środków wydatkowanych na utrzymanie wojska ${ }^{33}$. O przedkładaniu własnych interesów nad dobro publiczne świadczy uwaga, że „najwięcej to województwo, w którym to wojsko lokację mieć będzie, tracić"34.

15 stycznia na forum sejmowym dyskutowano sprawę podatków ze względu na brak postępów w tej materii. Nie szczędząc krytyki, posłowie byli zgodni co do tego, że ta sprawa stanęła w martwym punkcie. Analizując tok dyskusji, podskarbi nadworny litewski Antoni Dziekoński wskazywał na obawy właścicieli ziemskich, podkreślając ze zdumieniem, że po upływie czterech miesięcy od rozpoczęcia obrad sejmowych nie sformułowano konkretnego planu rozwiązań podatkowych ${ }^{35}$. Ciekawą wydaje się również opinia posła wołyńskiego Wojciecha Świętosławskiego, z której wynika, że sejm ignoruje instrukcje posłów z różnych regionów - jak określił: będące „prawidłem naszych czynności” - traktujące o konieczności modyfikacji podatków ${ }^{36}$. Jest to interesujący wątek, który bez wątpienia zasługuje na konfrontację ze źródłami omawiającymi działalność sejmików w niniejszym okresie.

W licznych wystąpieniach posłów z terenów Wielkiego Księstwa Litewskiego, powołujących się na instrukcje, przewijało się przekonanie o nieuchronności wprowadzenia zarówno podatku propinacyjnego, jak i podatków stałych. Za takim rozwiązaniem optowali poseł brasławski Tomasz Wawrzecki oraz poseł trocki Michał Brzostowski. Niemniej jednak, dbając o wspólne interesy stanowe i w obawie przed poniesieniem wysokich kosztów, opowiadali się oni za przerzuceniem ciężaru podatkowego na inne warstwy społeczne oraz opodatkowaniem w pierwszym rzędzie „duchownych funduszy i królewszczyzn”. W ostateczności,

w Warszawie rozpoczętego roku 1788, Warszawa, Druk. Nadworna J. K. Mci i [...] Kommis. Ed. Narod. 1790, t. 1, cz. 1-2; t. 2, cz. 1-2, http://www.wbc.poznan.pl/Content/32987/45.html (dostęp: 8 II 2015).

32 Diariusz Sejmu Czteroletniego (sesje 1-71)..., http://www.wbc.poznan.pl/Content/32987/46.html (dostęp: 8 II 2015).

${ }^{33}$ L. Ratajczyk, Wojsko i obronność..., s. 18.

${ }^{34}$ Diariusz Sejmu Czteroletniego (sesje 1-71)..., http://www.wbc.poznan.pl/Content/32987/46.html (dostęp: 8 II 2015).

${ }^{35}$ Ibidem, http://www.wbc.poznan.pl/Content/32987/50.html (dostęp: 8 II 2015).

${ }^{36}$ Ibidem. 
czyli jak to ujął poseł oszmiański Józef Kociełł, „co brakować będzie” miałaby wnieść szlachta ${ }^{37}$.

Nawiązując do dyskusji, Fryderyk Moszyński zaproponował uchwalenie podwójnego pogłównego żydowskiego, zrealizowanie nowego komputu wojska z funduszy wydatków nadzwyczajnych, pożyczki wewnętrznej oraz zwiększenia opłat stemplowych. Swoje uwagi motywował pragnieniem ochrony „obywatelów od uciążliwego i nierównego doczesnego podatku według projektu”. Zresztą 16 stycznia anonimowy autor apelował: „nie taksujecie dóbr ziemskich, dopóki królewszczyznami i dochodami duchownemi nie rozporządzicie" ${ }^{38}$. Nie dziwi więc, że 30 stycznia Jan Suchorzewski postulował wprowadzeniu trzykrotnie większego opodatkowania dóbr duchownych niż szlacheckich ${ }^{39}$.

Rzeczywiście perspektywy ponoszenia wysokich kosztów utrzymania rozbudowanego wojska niepokoiły szlachtę, która poszukiwała innych źródeł finasowania projektu $^{40}$.

O znaczeniu rozważań nad polityką fiskalną państwa świadczy mowa wygłoszona przez Tomasza Wawrzeckiego 29 stycznia $^{41}$. Miała ona charakter programowy, autor wymieniał ewentualne źródła zasilania budżetu, wymieniając „dobra i sumy pojezuickie”, „czopowe od win zagranicznych”, „licytacje propinacji” w miastach, „projekta akcyz w miastach”, podwójne pogłówne żydowskie. Uwzględnił także obciążenia $\mathrm{z}$ dóbr ziemskich, które jego zdaniem mają być nakładane nie w sposób arbitralny, lecz proporcjonalnie do dochodów: „szlachecki teraz podatek powinien być rozumniejszy, niż chłopski był dotąd”.

Należy więc podkreślić wprowadzenie do dyskusji pojęcia powszechności podatkowej, czyli obciążenia wszystkich stanów, w tym objęcie podatkami szlachty.

Przytoczone obserwacje skłaniają do wniosku, że pomimo dużego zaangażowania posłowie nie zagłębiali się w omawianie mechanizmu ściągania podatków. Pozostawał on poniekąd na uboczu debaty sejmowej, choć siłą rzeczy osiągnięcie jak największych wpływów wymagało organizacji efektywnego aparatu skarbowego $\mathrm{w}$ terenie. Wawrzecki - jak wynika to $\mathrm{z}$ analizy jego przemówienia - również nie dostrzegał problemu poboru podatków, nawiązując w swojej mowie do instytucji starostw, z których wcześniej opłacano kwartę oraz hibernę, a także proponując zaopatrywać wojsko w wozy i konie, proch i ołów przez miasta.

\footnotetext{
${ }^{37}$ Ibidem; T. Korzon, Wewnętrzne dzieje Polski za Stanisława Augusta..., t. 3, s. 229.

${ }^{38}$ Województw, ziem i powiatów do swoich posłów sejmujących roku 1788 i 1789, w: Zbiór mów i pism..., s. 12.

${ }^{39}$ Diariusz Sejmu Czteroletniego (sesje 1-71)..., http://www.wbc.poznan.pl/Content/32987/57.html (dostęp: 8 II 2015); M. Drozdowski, op. cit., s. 139.

${ }^{40}$ E. Rostworowski, Sprawa aukcji wojska..., s. 228-229; L. Ratajczyk, Wojsko i obronność..., s. 365.

${ }^{41}$ Diariusz Sejmu Czteroletniego (sesje 1-71)..., http://www.wbc.poznan.pl/Content/32987/56.html (dostęp: 8 II 2015).
} 
Pokrótce podsumowując materiał źródłowy, można poczynić wstępne wnioski. O ile dyskusja tocząca się w pierwszych miesiącach prac sejmu zmierzała ku usprawnieniu zarządu wojskiem oraz ustaleniu źródeł wpływów budżetowych, o tyle nie zawierała ona ani wskazówek co do sposobów ściągania świadczeń, ani tym bardziej żadnych konkretów w kwestii kompleksowych przemyśleń dotyczących administracji lokalnej. Nie ulega wątpliwości, że postulaty administracji lokalnej umykały uwadze posłów ze względu na brak świadomości, że dla realizacji daleko idących planów nie wystarczy uchwalenie konstytucji. Dążąc do uzyskania maksymalnych profitów poprzez dyslokacje jednostek w swoich dobrach oraz rozbudowę kawalerii, posłowie postrzegali kwestię podniesienia stanu liczebnego wojska z perspektywy kolidowania interesu publicznego z prywatnym, dbania o prywatne interesy $\mathrm{z}$ rzekomą troską o dobro ojczyzny.

5 lutego 1789 r. w trakcie dyskusji nad kształtem armii oraz ułożeniem jej etatu podskarbi wielki litewski Stanisław Poniatowski zgłosił czy raczej ponowił propozycję ustanowienia komisji wojewódzkich („komisji wojewódzkich wojskowo-cywilnych”, „komisji cywilno-wojskowych”, „komisje Boni Ordinis po w[ojewó]dztwach"), które zajmowałyby się rozmieszczeniem wojska w terenie, jego kwaterunkiem oraz furażowaniem ${ }^{42}$. Nowo powołane komisje wspólnie z Komisją Wojskową miały obmyślić „lokacje, furaże, i inne potrzeby dla tegoż wojska” oraz zapobiec „nagłym werbunkiem [...] nieregularnemu sposobowi postępowania sobie z obywatelami”, zapewnić „karność i posłuszeństwo wojska”43. Zaproponowany przez podskarbiego zakres działań komisji obejmował szeroki wachlarz zadań, dlatego - prawdopodobnie wychodząc z tych założeń - odniósł się on z rezerwą do pomysłu posła bracławskiego Seweryna Potockiego, sprowadzającego się do powołaniu do życia sądów cywilno-wojskowych.

\section{Wstępne projekty organizacji administracji terenowej}

20 lutego 1789 r. w sejmie wniesiono projekt Stanisława Potockiego dotyczący ustanowienia w czterech ukraińskich województwach komisji furażowych. Jak wynika $\mathrm{z}$ analizy głosów zabranych przez posłów województw podolskiego, wołyńskiego i kijowskiego, władze stanęły wobec konieczności zapobieżenia „rozruchom chłopskim” bądź - jak to było określone - „buntom chłopskim na Ukrainie” oraz planowanej dyslokacji wojsk. $Z$ treści dyskusji wynika także, że „komisje porządkowe czyli furażowe" miały działać na podstawie ordynansów wydawanych przez marszałków oraz „znieść się mają z komendami”.

${ }^{42}$ W. Kalinka, Sejm Czteroletni... (1895), t. 1, cz. 2, s. 546; idem, Sejm Czteroletni, t. 1, Warszawa 1991, s. 377.

${ }^{43}$ Diariusz Sejmu Czteroletniego (sesje 1-71)..., http://www.wbc.poznan.pl/Content/32987/61.html (dostęp: 8 II 2015). 
Czyniąc solidny ekskurs historyczny do wydarzeń z lat 1648 i 1768, poseł kijowski Mikołaj Proskura uzasadniał powołanie do życia komisji względami bezpieczeństwa „obywateli województw ruskich”, którzy są zgodni co do pokrycia kosztów stacjonowania żołnierzy. „Imieniem w[ojewó]dztwa mego” upraszał sejm o zlecenie Komisji Wojskowej wysłania wojska na Ukrainę. Nie sposób nie zauważyć, że niniejsza wzmianka pozwala wysnuć przypuszczenie o oddolnej reakcji właścicieli ziemskich stymulującej debatę sejmową oraz podjęcie odpowiednich uchwał.

Za nie mniej interesującą należy uznać uwagę posła poznańskiego Adama Moszczeńskiego, który 20 lutego zaznaczał, że jest „równie urzędnikiem i komisarzem w[ojewódz]twa bracławskiego, które w krytycznym czasie zjechawszy się, obrało komisarzów, a potym to per laudum na sejmikach aprobowało". Wypowiedź posła wyraźnie wskazuje, że w województwie bracławskim taka komisja już pracowała, decyzję o obraniu komisarzy podjęto zaś na sejmiku, z czego wynikałoby, że jej założenie nie było efektem przemyślanego lub szczegółowo opracowanego programu sejmowego rozbudowy zarządu lokalnego, lecz było lokalną inicjatywą szlachty ${ }^{44}$.

23 lutego w województwach ruskich ustanowiono „komisje porządkowe [...] dla obmyślenia furażów i innych potrzeb wojska krajowego". Uwzględniając zaistniałą sytuację, sejm nałożył na komisje obowiązek utrzymania porządku i bezpieczeństwa. Komisje te miały się ustosunkowywać do uniwersałów „marszałków konfederacji generalnej”, czyli były podporządkowane sejmowi, a także miały kontaktować się z komendami wojskowymi ${ }^{45}$.

Omawiając późniejsze, marcowe wydarzenia, Walerian Kalinka stwierdził, że komisja „prowiancka w porządkową zmieniła się"46, co wskazuje na konieczność szerszego przedstawienia tego zagadnienia, a także kwestii ewentualnych relacji pomiędzy komisjami furażowymi i cywilno-wojskowymi. Toteż w chwili obecnej nie sposób jednoznacznie odpowiedzieć, w jakim stopniu komisje te mogły stanowić podwaliny przyszłej administracji terenowej.

Dążąc do zwiększenia wpływów skarbowych, Sejm Czteroletni wybrał drogę modyfikowania systemu podatkowego. W końcu stycznia 1789 r. uchwalono podwójne podymne, z którego spodziewano się uzyskać $7 \mathrm{mln} \mathrm{z}^{47}$. Inicjatywę miał sfinansować bankier Piotr Tepper poprzez zaciągnięcie pożyczki w Genui ${ }^{48}$.

\footnotetext{
${ }^{44}$ Ibidem, http://www.wbc.poznan.pl/Content/32987/65.html (dostęp: 8 II 2015); Pamiętniki z ośmnastego wieku, t. 7, Poznań 1867, s. 103; W. Kalinka, Sejm Czteroletni... (1895), t. 1, cz. 2, s. 434.

${ }^{45}$ Opatrzenie bezpieczeństw województw ruskich, w: Volumina legum..., t. 9, s. 71.

${ }^{46}$ W. Kalinka, Sejm Czteroletni... (1895), t. 1, cz. 2, s. 477.

${ }^{47}$ Ofiara na pierwsze potrzeby wojska W. X. Litt., w: Volumina legum..., t. 9, s. 65-66; W. Kalinka, Sejm Czteroletni... (1895), t. 1, cz. 2, s. 532; idem, Sejm Czteroletni... (1991), t. 1, s. 368; T. Korzon, Wewnętrzne dzieje Polski za Stanisława Augusta..., t. 3, s. 228.

${ }^{48}$ W. Kalinka, Sejm Czteroletni... (1895), t. 1, cz. 2, s. 552.
} 
26 lutego Kasper Czyż przedłożył sejmowi projekt Michała Bernowicza „z intrat dóbr ziemskich grosz dziesiąty od sta, do półtora podymnego [...]; z dóbr duchownych dwadzieścia od sta, a z królewszczyzn 50. od sta”. W taki sposób na początku marca wprowadzono pierwszy stały podatek nałożony przez szlachtę na swoje dobra. Dobra szlacheckie opodatkowano w wysokości 10\% dochodu, duchowne zaś w wysokości 20\%. Podwójną kwartą obciążono królewszczyzny ${ }^{49} .30$ marca 1789 r. Stanisław August ofiarował na wojsko "całość dochodów i prowentów”, prowent czopowego z Grodna i Brześcia ${ }^{50}$. 6 kwietnia sejm uchwalił konstytucję subsidium charitativum ${ }^{51}$.

Sam fakt uchwalenia podatków nie gwarantował jeszcze oczekiwanych wpływów do skarbu. Zresztą - co trzeba zauważyć - od końca 1788 do maja 1789 r. udało się zgromadzić $29 \mathrm{mln}$ zł, tymczasem zaplanowane wydatki na wojsko opiewały na kwotę blisko $48 \mathrm{mln} \mathrm{z}^{52}$. Niedobór wpływów skarbowych był wynikiem niedoskonałości systemu podatkowego, ponieważ o wiele bardziej skomplikowane okazało się techniczne wykonanie zadania, pociągające za sobą konieczność ustalenia sposobów poboru świadczeń ${ }^{53}$.

Zawód, który spotkał ustawodawców, był wynikiem zaniżania przez właścicieli ziemskich w zeznaniach wysokości dochodów jako podstawy obliczania podatków ${ }^{54}$. Oprócz tego nie bez znaczenia były fakty przerzucania podatku propinacyjnego na poddanych ${ }^{55}$.

Nie ulega wątpliwości, że w celu usprawnienia polityki fiskalnej konieczne wydawałoby się wdrożenie skutecznych rozwiązań administracyjnych, z brakiem którym należało wiązać problem braku pokrycia asygnacji Komisji Skarbowej $\mathrm{w}$ kasach powiatowych ${ }^{56}$. Unaocznione problemy finansowe, brak rzetelnych danych o całokształcie stosunków społeczno-gospodarczych w terenie wyłonił problem dokładnego rozeznania oraz zgromadzenia materiałów statystycznych ${ }^{57}$, wskazując tym samym na brak sprawnego zarządzania na szczeblu lokalnym.

49 T. Korzon, Wewnętrzne dzieje Polski za Stanisława Augusta..., t. 3, s. 234-235.

${ }^{50}$ Ofiara od nas Króla, w: Volumina legum..., t. 9, s. 72; Pamiętniki z ośmnastego wieku..., t. 7, s. 102; W. Kalinka, Sejm Czteroletni... (1895), t. 1, cz. 2, s. 565; T. Korzon, Wewnętrzne dzieje Polski za Stanisława Augusta..., t. 3, s. 233.

${ }^{51}$ Ofiara wieczysta prowincjów obojga narodów na powiększenie sił krajowych, w: Volumina legum..., t. 9, s. 73-74.

${ }^{52}$ W. Kalinka, Sejm Czteroletni... (1895), t. 1, cz. 2, s. 565, 569, 629; idem, Sejm Czteroletni... (1991), t. 1, s. 233.

${ }^{53}$ M. Drozdowski, op. cit., s. 138.

${ }^{54}$ L. Ratajczyk, Wojsko i obronność..., s. 382; Z. Zielińska, Ostatnie lata Pierwszej Rzeczypospolitej, Warszawa 1986, s. 48-49.

${ }^{55}$ W. Kalinka, Sejm Czteroletni... (1895), t. 1, cz. 2, s. 566; R. Rybarski, Skarbowość Polski w dobie rozbiorowej, Kraków 1937, s. 245.

56 W. Kalinka, Sejm Czteroletni... (1895), t. 1, cz. 2, s. 637-642; idem, Sejm Czteroletni... (1991), t. 1, s. 438.

${ }^{57}$ W. Kalinka, Sejm Czteroletni... (1895), t. 1, cz. 2, s. 637-643; idem, Sejm Czteroletni... (1991), t. 1, s. 391, 438; R. Rybarski, op. cit., s. 44, 432, 435; L. Ratajczyk, Przyczynek do sprawy..., s. 64. 
W maju 1789 r. w sejmie pochylono się na projektem podatkowym, stopniem obciążeń fiskalnych szlachty, mieszkańców miast oraz przedmieść. Zapoznanie się z debatą legislacyjną dotyczącą „materii podatkowej” ukazuje poruszenie kwestii wprowadzenia komisji terenowych. 11 maja poseł wołyński Walerian Stroynowski wysunął pod rozwagę propozycję o odsyłaniu poprzez komisje powiatowe danych o dochodach do Komisji Skarbowej, która zdaniem marszałka Kazimierza Sapiehy „proporcjonalnie odciągnąwszy z każdej wsi, co płacić będzie należało, z reszty grosz dziesiąty ustanowi”. O składaniu przez właścicieli ziemskich inwentarzy do komisji powiatowych wzmiankuje także poseł bracławski Seweryn Potocki. Wątek „projektu dla komisji wojewódzkiej” przewijał się do 19 maja. 22 maja głos zabrał Stanisław August, składając propozycję, by do ustalenia wysokości podatku oraz sposobów jego pobierania zobligowano „komisje udzielne po województwach, ziemiach i powiatach". O zaawansowanym stopniu prac nad komisjami świadczą materiały z 25 maja, kiedy „województwa” składały listy komisarzy. Marszałek Sapieha podkreślił, że na sesji prowincjonalnej obrano trzy komplety dla każdego województwa i powiatu. Następnego dnia w sejmie odczytano listy komisarzy.

Debata nad nowym organem terenowym trwała do końca. 29 maja Mateusz Butrymowicz przekonywał posłów, że za podstawę obliczenia podatku należy wziąć intraty składane do komisji wojewódzkiej przez właścicieli dóbr, ponieważ - jak tłumaczył - „lustracji nowych do tych dóbr wysłać już nie można”. Poniekąd wtórował mu poseł gnieźnieński Antoni Rożnowski, który na sesji 9 czerwca przedłożył projekt o zbliżonej treści, sprowadzający się do dobrowolnego złożenia intrat w komisjach wojewódzkich przez "posesorowie starostw” w celu wyznaczenia wysokości kwarty oraz późniejszej lustracji ${ }^{58}$.

30 maja 1789 r. sejm uchwalił konstytucję Sposób wynalezienia ofiary, na mocy której powołano do życia komisje terenowe. Do zadań nowo ustanowionych organów należało dokonanie lustracji dóbr, przeanalizowanie wysokości intrat, ułożenie wymiaru renty dla włościan oraz wyznaczenie „dobrowolnej ofiary dziesiątego grosza" na wojsko ${ }^{59}$. Komisarze byli zobowiązani dostarczyć jeden egzemplarz inwentarza do Komisji Skarbowej ${ }^{60}$.

Zgodnie z treścią konstytucji „obywatele każdego respective województwa” mieli wybrać 15 komisarzy do każdej komisji „podług dawnych praw i zwyczajów", co było odwołaniem do tradycji samorządu sejmikowego. Niemniej

${ }^{58}$ Diariusz Sejmu Czteroletniego (sesje 98-198 i 327), z rękopisu przechowywanego w AGAD (w zbiorze Archiwum Sejmu Czteroletniego, rozproszony w różnych tomach) autorstwa Jana Pawła Łuszczewskiego, Antoniego Siarczyńskiego i in., http://www.wbc.poznan.pl/Content/32995/116.html (dostęp: 8 II 2015).

${ }^{59}$ Sposób wynalezienia ofiary $z$ dóbr ziemskich i duchownych $w$ Koronie i w Wielkim Księstwie Litewskim, w: Volumina legum..., t. 9, s. 77-95; B. PAU i PAN, rkps 568, k. 5; W. Kalinka, Sejm Czteroletni... (1895), t. 1, cz. 2, s. 568-569.

${ }^{60}$ Sposób wynalezienia ofiary..., s. 77, 91-93; W. Kalinka, Sejm Czteroletni... (1991), t. 1, s. 392. 
jednak uzasadniając swoją decyzję pilnymi potrzebami, ustawodawcy wyznaczyli komisarzy, stosując formułę "pro hac sola vice et nunquam practicanda”. Zresztą na fakt odgórnego wyznaczenia komisarzy zwrócili uwagę Tadeusz Korzon i Walerian Kalinka ${ }^{61}$.

W lipcu 1789 r. ukazał się szereg uniwersałów Komisji Skarbowej skierowanych do komisji wojewódzkich. Jeden z nich stanowił żądanie dostarczenia „cen pańszczyzny, zboża, innych danin oraz przełożeniem skarg w niektórych punktach przezacnego duchowieństwa"62. W końcu lipca Komisja wydała uniwersał traktujący o dokonaniu przez komisje wojewódzkie szacunku „wielości gospodarzów rolniczych, czynszowników, chałupników, komorników, fabrykantów i rzemieślników, kupców i handlujących, karczmarzów i szynkarzów, czeladzi służącej i luźnej oraz zarobkiem żyjących żebraków". Komisja nadmieniła o konieczności przygotowania spisów ludnościowych, w tym gruntownego spisania ludności żydowskiej i karaimskiej ${ }^{63}$.

Z początku lipca 1789 r. pochodzi uniwersał zobowiązujący właścicieli ziemskich do stawiania się przed grodzieńską komisją powiatową celem złożenia inwentarzy intraty z dochodów $\mathrm{z}$ lat $1786-1788^{64}$. Zachowane lustracje dymów dóbr ekonomii grodzieńskiej z sierpnia 1789 r. stanowią potwierdzenie egzekwowania zarządzenia. Co ciekawe, pod tymi dokumentami widnieją podpisy komisarzy powiatu grodzieńskiego oraz Franciszka Boufałła, „prezydującego w komisji podatkowej p[owia]tu grodzieńskiego". Efektem prac komisarzy była pierwsza gruntowna lustracja dymów w dobrach duchownych i świeckich, przeprowadzona w województwie trockim ${ }^{65}$. Na 28 października 1789 r. datuje się lustracja dymów sporządzona przez komisarzy województwa nowogródzkiego ${ }^{66}$.

Zapoznanie się z diariuszem sejmowym dowodzi, że próby wprowadzenia nowych form ustrojowych na szczeblu lokalnym pozostawiały wiele do życzenia. Za bardzo wymowne w tym względzie należałoby uznać przemówienie wygłoszone przez Mateusza Butrymowicza. 3 sierpnia 1789 r. poseł piński oświadczył, że odebrał anonimowy list od obywatela z powiatu lidzkiego, donoszącego o czynnościach komisji powiatowej. $Z$ treści petycji wynikało, że komisarze są zaabsorbowani załatwianiem własnych interesów, skłonny był więc zaproponować nową obsadę komisji. Kontynuując, zarzucił komisarzom zaniżenie cen zboża, stosowane wbrew prawu bez wspólnej narady z „urzędnikami i współpowietnikami”.

\footnotetext{
${ }^{61}$ T. Korzon, Wewnętrzne dzieje Polski za Stanisława Augusta..., t. 3, s. 236-237; W. Kalinka, Sejm Czteroletni... (1895), t. 1, cz. 2, s. 568.

${ }^{62}$ AGAD, tzw. ML, IX 27, k. 304; IX 44, k. 84; B. Czartoryskich, rkps 1178, k. 29.

${ }^{63}$ AGAD, tzw. ML, IX 27, k. 304; IX 44, k. 47.

${ }^{64}$ AGAD, tzw. ML, IX 44, k. 55.

${ }^{65}$ LPAH, SA 4057, f. 11, op. 1, nr 333; SA 4056, f. 11, op. 1, nr 18, nr 332, k. 116; f. 1282, op. 1 , nr 5820.

${ }^{66}$ B. Uniwersytetu Wileńskiego, RS, F 57 B 54, nr 51.
} 
Drugi zarzut dotyczył wniesienia subsidium charitativum nie do kancelarii grodzkiej, lecz do „do kancelariów biskupich”67.

Korzystając z okazji i dążąc do ukazania obiektywnego obrazu poczynań komisji, Butrymowicz przedstawił sytuację w powiecie pińskim. Podkreślał, że jego komisja podatkowa w miarę możliwości próbuje rozwiązać kwestię nakładanych świadczeń. Po pierwsze „regestra trzech lat ostatnich znosi i na trzy części one rozdzieliwszy, trzecią część równą na wysiew do podatku kładzie”. Po drugie, zdaniem posła, komisja zaradziła w sytuacji niesprzyjających warunków pogodowych (powodzi i w deszczowych okresach letnich) stosować sprawiedliwe ceny. Konkludując, wezwał sejm do zajęcia stanowiska wobec wyżej przestawionej prośby. Nie był to głos odosobniony. W sierpniu ujawniły się problemy z przeprowadzeniem lustracji królewszczyzn ${ }^{68}$. Jak można sądzić, okoliczności te przyczyniły się do czytania projektu Warunek dla komisarzy wojewódzkich, które odbyło się 14 sierpnia ${ }^{69}$.

Przedstawione wyżej materiały wskazują, że za swoje główne zadanie sejm uważał usprawnienie administracji podatkowej, przy którym kwestia administracji lokalnej wydawała się być słabo dostrzegalna. Inaczej mówiąc, komisje odgrywały rolę swoistego instrumentu realizowania polityki skarbowo-wojskowej.

Jak można wnioskować, podjęte przez sejm decyzje o utworzeniu komisji furażowych oraz powiatowych należałoby potraktować w kategoriach działań doraźnych, narzuconych przez zaistniały zbieg okoliczności.

Choć przewodnią ideą regulacji prawnej nie był zarząd terenowy sensu stricto, powołanie do życia nowych podmiotów należy uznać za kolejny krok na drodze do poszukiwań skutecznych rozwiązań administracyjnych. Poza tym w pewnym stopniu analiza dyskusji sejmowej nasuwa spostrzeżenie o procesie kształtowania się zalążków prawa administracyjnego ${ }^{70}$. Posłowie próbowali określić stosunki pomiędzy komisjami wojewódzkimi a Komisją Skarbową oraz sejmem, czego dowodzi dyskusja, która odbyła się 18 sierpnia $^{71}$.

Zgodnie z konstytucją sejmową komisje były zobowiązane do sfinalizowania swoich prac „najdalej na ostatni dzień września”72. Tymczasem różne względy (niezadowolenie właścicieli ziemskich z odgórnej regulacji cen, wpływ warunków atmosferycznych, brak zaprzysiężenia intrat we właściwym czasie oraz inne wątki natury psychologicznej) zadecydowały o konieczności kontynuacji

${ }^{67}$ Diariusz Sejmu Czteroletniego (sesje 98-198 i 327)..., http://www.wbc.poznan.pl/Content/32995/ 133.html (dostęp: 8 II 2015).

${ }^{68}$ Ibidem, http://www.wbc.poznan.pl/Content/32995/140.html (dostęp: 8 II 2015).

${ }^{69}$ Ibidem.

${ }^{70}$ J. Malec, Narodziny polskiego prawa administracyjnego, w: idem, Studia z dziejów administracji nowożytnej, Kraków 2003, s. 99-111.

${ }^{71}$ Diariusz Sejmu Czteroletniego (sesje 98-198 i 327)..., http://www.wbc.poznan.pl/Content/32995/142.html (dostęp: 8 II 2015).

${ }^{72}$ Sposób wynalezienia ofiary..., s. 91. 
$\operatorname{prac}^{73} .12$ października ze względu na brak jednolitej stawki opodatkowania oraz zaniżone ceny produktów rolnych przedłożono, aby wprowadzić pewne regulacje w organizacji pracy komisarzy ${ }^{74}$. Zresztą 22 października Stanisław Kostka Potocki, odwołując się do faktów zaniżenia cen produktów - przez co „ten grosz 10ty cierpi w wielu miejscach niesprawiedliwość" - stwierdził, że komisje wojewódzkie nie stosują się do litery prawa, domagając się tym samym ustanowienia komisji koekwacyjnej ${ }^{75}$.

Zgodnie z ustawą komisje powiatowe wykonywały swoje czynności do końca roku, mając „najdalej na 15 dzień grudnia pod rygorem prawa” złożyć w komisjach skarbowych „sumariusze szczegółów intrat obywatelów duchownych i świeckich i miast"76.

\section{Projekt o komisjach cywilno-wojskowych}

Lato i jesień 1789 r. z różnych względów są uważane za przełomowy okres w pracach sejmowych. Fakt zbliżenia się stronnictwa patriotycznego z królem oraz nowy układ stosunków z Prusami nie pozostawały bez wpływu na przyspieszenie prac ustrojowych ${ }^{77}$.

W celu opracowania projektu przemian ustrojowych 7 września 1789 r. sejm wyłonił Deputację do ułożenia projektu do nowej formy rządu. Tegoż dnia Seweryn Potocki z mównicy sejmowej zapytywał: „Jak rządność aż do ostatnich granic naszych przez komisje wojewódzkie zaszczepić?"78. Z tego głosu można byłoby wnioskować, że instytucjom tym przydawano istotną rolę.

Zważywszy na zaistniałą sytuację, na drugą połowę roku przypada nasilenie się dyskusji na temat kształtu zarządu terenowego. Ze względu na stan źródeł oraz zarysowane wyżej ramy niniejszych rozważań nie sposób dokonać skrupulatnej analizy prac legislacyjnych w zakresie tworzenia zrębów administracji terytorialnej. Niemniej jednak zapoznanie się z zawartością diariusza sejmowego rzuca pewne światło na okoliczności przygotowania i uchwalenia projektu.

W diariuszu sejmowym 15 czerwca spotykamy lakoniczny zapis o czytaniu „znowu drugi projekt pod tytułem Komisje Wojewódzkie i Cywilno-Wojskowe”,

${ }^{73}$ Diariusz Sejmu Czteroletniego (sesje 98-198 i 327)..., http://www.wbc.poznan.pl/Content/32995/ 160.html (dostęp: 8 II 2015).

${ }^{74}$ Ibidem, http://www.wbc.poznan.pl/Content/32995/171.html (dostęp: 8 II 2015).

${ }^{75}$ Ibidem, http://www.wbc.poznan.pl/Content/32995/177.html (dostęp: 8 II 2015).

${ }^{76}$ Ibidem, http://www.wbc.poznan.pl/Content/32995/184.html (dostęp: 8 II 2015).

${ }^{77}$ Prusy wiązały podpisanie traktatu z koniecznością określenia formy rządu Rzeczypospolitej; E. Rostworowski, Ostatni król Rzeczypospolitej..., s. 168-171; W. Kalinka, Sejm Czteroletni... (1895), t. 1, cz. 2, s. 656, 685; A. Lityński, op. cit., s. 68.

${ }^{78}$ Diariusz Sejmu Czteroletniego (sesje 98-198 i 327)..., http://www.wbc.poznan.pl/Content/32995/152.html (dostęp: 8 II 2015). 
który miał być dyskutowany na sesji prowincjonalnej ${ }^{79}$. Choć nie mamy szczegółowych informacji na temat debaty o tym - notabene drugim - projekcie, jego tytuł sugeruje prowadzenie prac w zakresie poszukiwań modelu zarządu szczebla lokalnego. Jak można sądzić, posłowie wyciągali wnioski z czynności podejmowanych przez komisje powiatowe, koncentrując się na doprecyzowaniu projektu $\mathrm{z}$ uwzględnieniem głosów nadchodzących $\mathrm{z}$ rożnych regionów kraju. Przemawia za tym przebieg dyskusji.

W sierpniu 1789 r. poseł inflancki Julian Ursyn Niemcewicz postulował uzupełnienie szeregów wojskowych poprzez obowiązkowe dostarczanie rekrutów, ustanowienie magazynów dla dyslokacji jazdy. Podkreślał, że podjęcie decyzji o założeniu komisji wojewódzkich uważał „za jedną z najpotrzebniejszych sejmu naszego ustaw”, które miały stosować się do „rozkazów najwyższego rządu” oraz zaprowadzą "porządek w miastach i powiatach" 80 .

Próbując podsumować dokonania sejmu, 10 sierpnia 1789 r. Stanisław Krasicki wypowiedział się w następny sposób: „Co żeśmy w dziesięciomiesięcznym sejmowania czasie dokazali? [...] Urządziliśmyż zupełnie opisy choć jednej magistratury krajowej? Przywiedliśmyż przynajmniej to już do istotnego skutku i końca co najpierwszym i najcelniejszym obrad naszych być miało zamiarem i obowiązkiem? To jest wojsko, podatek i poprawa rządu; wojsko jest dopiero w etacie, podatek w komisjach, poprawa rządu w projekcie"81. Przemówienie to - choć niewolne od patosu - charakteryzowało zwięźle wizję reform skarbowo-wojskowych i administracyjnych.

Zapoznanie się z zawartością diariusza sejmowego wskazuje na ożywienie dyskusji nad komisjami terenowymi w październiku 1789 r. Wśród wielu głosów nawołujących do zajęcia się projektem komisji cywilno-wojskowych należy zwrócić uwagę na kilka najbardziej wymownych, oddających istotę dyskusji. Zdaniem kasztelana sądeckiego Józefa Ankwicza ich założenie - „aż nadto potrzebne podług tych doniesień, które zewsząd przychodzą" - miało przyczynić się do usprawnienia systemu zaopatrzenia i zakwaterowania wojska ${ }^{82}$. Oczywiście cytat ten - choć nie zawiera żadnych szczegółów - świadczyć może o głosach dochodzących z różnych zakątków kraju.

Bardziej powściągliwą postawę zaprezentował poseł żmudzki Stanisław Górski, który 22 października położył nacisk na ogromne koszty projektu. Podkreślał bowiem, że „będziemy mieli dopiero najmniej dziesięć tysięcy poborców czyli rewizorów domów szlacheckich i kosztowniejszych skarbowi niż 10000 wojska".

\footnotetext{
${ }^{79}$ Ibidem, http://www.wbc.poznan.pl/Content/32995/118.html (dostęp: 8 II 2015).

${ }^{80} \mathrm{Ibidem}$, http://www.wbc.poznan.pl/Content/32995/144.html (dostęp: 8 II 2015); L. Ratajczyk, Wojsko i obronność..., s. 120.

${ }^{81}$ Diariusz Sejmu Czteroletniego (sesje 98-198 i 327)..., http://www.wbc.poznan.pl/Content/32995/137.html (dostęp: 8 II 2015).

${ }^{82}$ Ibidem, http://www.wbc.poznan.pl/Content/32995/167.html (dostęp: 8 II 2015).
} 
Dlatego proponował ograniczyć się do powołania „komisji w każdym województwie jedną"83.

Należałoby odnieść się z rezerwą do stwierdzenia Emanuela Rostworowskiego, że w ciągu trzech miesięcy prace Deputacji nie posunęły się naprzód ${ }^{84}$. Jak wynika z analizy źródeł, 6 listopada marszałek Kazimierz Sapieha w swoim przemówieniu wspomniał komisję sejmową, która zajmowała się komisjami cywilno-wojskowymi oraz akcentował „niezliczone mnóstwo składających ją opisów”. Jak można sądzić, fakt przedstawienia różnych projektów zmusił stany sejmujące do zwrócenia się do posłów Tomasza Wawrzeckiego i Michała Bernowicza, „aby się zaprzątnęli projektem komisjów wojewódzkich" ${ }^{\text {" }}$.

Nie dysponujemy materiałami informującymi o dokładnym przebiegu tych prac. Wiadomo jednak, że już 13 listopada poseł żmudzki Stanisław Górski przedłożył projekt jednomyślnie uzgodniony przez „reprezentantów prowincji lit[ewskiej]”, prosząc marszałka „o podniesienie projektów komisjów cywilno-wojskowych i onego do decyzji wzięcie”. Nadmienił, że projekt uwzględnia kwestię poboru i dostarczania rekruta, dyslokacji regimentów, ich zaopatrzenia oraz „sądu cywilno-wojskowego". Analiza mowy nasuwa następujące wnioski. Kwintesencją rozważań posła było wojsko oraz brak odpowiednich środków. Sformułowanie „powszechnie przyjęte układy komisjów wojewódzkich dla prowincji lit[ewskiej]” mogłoby wskazywać, że mamy do czynienia nie tyle z teoretycznymi przemyśleniami prawodawców, ile z czerpaniem z praktycznych rozwiązań ustrojowych, czyli doświadczeń komisji powołanych do życia w maju $1789 \mathrm{r}^{86}$

17 listopada marszałek Sapieha przy poparciu króla wniósł propozycję zapoznania się z projektem: „aby projekt Prowincji Litt: względem komisjów powiatowych, jaką przez całą prowincją ugodzony i wewnętrznego jej urządzenia tyczący się znalazł w decyzji pierwszeństwo"87. Dwa dni później sejm uchwalił konstytucję Komisje wojewódzkie i powiatowe w Wielkim Księstwie Litewskim $^{88}$, ustanawiającą nowe ogniwa władzy wykonawczej w terenie. Ze względu na to, że wybór komisarzy przypadał na luty, a „w tym przeciągu czasu wypadać mogą ustawiczne okoliczności do urządzenia między wojskiem a obywatelami” stany sejmujące podjęly decyzję, że komisarze powiatowi - jak określono:

\footnotetext{
${ }^{83}$ Ibidem, http://www.wbc.poznan.pl/Content/32995/177.html (dostęp: 8 II 2015).

${ }^{84}$ B. Leśnodorski, Dzieło Sejmu Czteroletniego, Wrocław 1951, s. 145-157; E. Rostworowski, Ostatni król Rzeczypospolitej..., s. 172-174.

${ }^{85}$ Diariusz Sejmu Czteroletniego (sesje 98-198 i 327)..., http://www.wbc.poznan.pl/Content/32995/185.html (dostęp: 8 II 2015); T. Korzon, Wewnętrzne dzieje Polski za Stanisława Augusta..., t. 5, s. 196.

${ }^{86}$ Diariusz Sejmu Czteroletniego (sesje 98-198 i 327)..., http://www.wbc.poznan.pl/Content/32995/189.html (dostęp: 8 II 2015).

${ }^{87} \mathrm{Ibidem}$, http://www.wbc.poznan.pl/Content/32995/191.html (dostęp: 8 II 2015); W. Kalinka, Sejm Czteroletni... (1895), t. 1, cz. 2, s. 643.

${ }^{88}$ Komisje wojewódzkie i powiatowe w Wielkim Księstwie Litewskim..., s. 136-142.
} 
„którzy odbierali intratę dziesiątego grosza” - mieli zapoczątkować prace nowych organów 15 grudnia $^{89}$.

Z całą pewnością nowo powstałe komisje porządkowe cywilno-wojskowe skorzystały z doświadczeń rozwiązań ustrojowych wprowadzonych w maju 1789 r., kontynuując czynności swoich poprzedniczek - komisji powiatowych (podatkowych). Toteż - jak się wydaje - stworzenie prawnoustrojowych podstaw dla działania nowożytnego państwa w terenie nie było rezultatem wyłącznie teoretycznego, odgórnie przygotowanego i oderwanego od rzeczywistości projektu.

\section{Klimat intelektualny i kulturalny epoki oświecenia}

W okresie Sejmu Czteroletniego myśl polityczna Rzeczypospolitej szukała własnych rozwiązań ustrojowych, skupiając się nie tyle na recypowaniu rozwiązań administracyjnych, ile na wprowadzeniu w życie form ustrojowych w znacznym stopniu czerpiąc z rodzimej tradycji ${ }^{90}$. Nie oznacza to oczywiście, że publicystyka społeczno-polityczna okresu stanisławowskiego nie skupiała uwagi na europejskiej myśli prawnoustrojowej ${ }^{91}$ oraz ustrojach państw obcych. Do angielskiej monarchii parlamentarnej odwoływał się Stanisław Konarski, a do amerykańskich doświadczeń ustrojowych nawiązywał Hugo Kołłątaj. Wiadomości o reformach ustrojowych w Europie znalazły również oddźwięk na łamach polskich czasopism będących ważnym elementem ówczesnego życia umysłowego. Na przykład na łamach „Pamiętnika Historyczno-Politycznego” oraz „Gazety Warszawskiej” szeroko omawiano francuskie i szwedzkie przeobrażenia ustrojowe. Do Rzeczypospolitej przenikały idee Monteskiusza, angielskiej myśli ekonomicznej i kameralistyki austriacko-niemieckiej ${ }^{92}$.

By uniknąć uproszczonych wywodów o stopniu zainteresowania ówczesnymi europejskich prądami umysłowymi ${ }^{93}$, wypada poprzestać na stwierdzeniu, że idee oświeceniowe były znane w Rzeczypospolitej, wywierały określony wpływ na życie umysłowe, trafiając jednak do ograniczonej grupy adresatów-intelektualistów.

Próby uchwycenia ich związku z postawami ówczesnych elit lub pracami legislacyjnymi w zakresie rozwiązań instytucjonalno-prawnych oraz tym bardziej

${ }^{89}$ Diariusz Sejmu Czteroletniego (sesje 98-198 i 327)..., http://www.wbc.poznan.pl/Content/32995/ 192.html (dostęp: 8 II 2015).

90 A. Grześkowiak-Krwawicz, Publicystyka stanisławowska o modelu rządów monarchii francuskiej, Wrocław 1990, s. 11-12, 17; J. Malec, Polska myśl administracyjna..., s. 143.

${ }^{91}$ A. Grześkowiak-Krwawicz, op. cit., s. 10.

${ }^{92}$ B. Leśnodorski, op. cit., s. 59-131; E. Lipiński, Studia nad historia polskiej myśli ekonomicznej, Warszawa 1956, s. 351; J. Malec, Studia z dziejów administracji..., s. 28; idem, Polska myśl administracyjna..., s. 25, 141-146; G.L. Seidler, W nurcie Oświecenia, Lublin 2002, s. 141.

${ }^{93}$ B. Leśnodorski, op. cit., s. 59-131; A. Zahorski, op. cit., s. 20-29; J. Malec, Studia z dziejów administracji..., s. 38. 
praktycznymi rozwiązaniami ustrojowymi nie należą do zadań łatwych. Jerzy Malec jest zdania, że osiemnastowieczne traktaty z zakresu nauki policji mogły nie pozostawać bez wpływu na reformy administracyjne w państwach europejskich. Jednocześnie podkreśla, że analiza oddziaływań niemieckich rozważań filozoficznoprawnych oraz kameralistycznych lub francuskiej nauki policji na polską myśl administracyjną zasługuje na dogłębne badania porównawcze ${ }^{94}$. Toteż omówienie procesu przenikania umysłowych prądów oświecenia i znajomości literatury europejskiej w dziedzinie prawnoustrojowej w Rzeczypospolitej nie wyczerpuje zagadnienia.

W związku z tym za pierwszoplanowe dla niniejszych rozważań należy uznać ustalenie ewentualnych relacji między ideą i teorią - zarówno rodzimą, jak i europejskimi doktrynami ustrojowo-administracyjnymi i ekonomicznymi - a pracami ustawodawczymi oraz formami administracji publicznej. Nie należy to zadanie do łatwych.

Zapoznanie się z rozważaniami polskich pisarzy politycznych z pierwszej połowy XVIII w. nasuwa wniosek o marginesowym traktowaniu zagadnienia administracji lokalnej.

Ówcześni myśliciele w znacznym stopniu skupiali uwagę na wątkach uznawanych za bardziej charakterystyczne, m.in. relacjach zachodzących pomiędzy władzą a społeczeństwem lub prezentowały opinie autora o sukcesji tronu, pochodzeniu władzy monarszej czy systemie sprawowania władzy ${ }^{95}$. Nie oznacza to jednak, że całkowicie ten wątek ignorowano.

Jednym z pierwszych, który ów problem poruszył, był Jakub Henryk Flemming. W złożonym w 1714 r. projekcie stwierdzał: „Radziłbym izby administracyjne po województwach, a wojewodowie byliby prezesami onych, dozwoliłbym aby każde województwo podało plan do wewnętrznego w nim zarządu, jakiby sądziło najkorzystniejszym dla siebie" 96 . Za utworzeniem rad wojewódzkich składających się z wojewody i czterech deputowanych oraz marszałka sejmikowego opowiadał się Stanisław Leszczyński ${ }^{97}$. Nie sposób nie zauważyć, że postulaty wprowadzenia

\footnotetext{
${ }^{94}$ Jerzy Malec zwraca uwagę na to, że „wielu ówczesnych autorów najprawdopodobniej nie było zaznajomionych bliżej z jej dorobkiem i tworzyło z potrzeby chwili, wysuwając - na podstawie obserwacji stosunków polskich i własnych przemyśleń - konkretne postulaty reorganizacji administracji”, idem, Polska myśl administracyjna..., s. 25, 27, 141-143.

95 A. Grześkowiak-Krwawicz, op. cit., s. 13-15, 27-29, 63.

${ }^{96}$ Archiwum tajne Augusta II czyli zbiór aktów urzędowych z czasów panowania tego monarchy, Wrocław 1843, s. 7-8.

${ }^{97}$ W rozdziale Senat swego traktatu Głos wolny wolność ubezpieczajacy zauważa: „Mówiąc dalej o sposobie praw egzekucji, nie przychodzi mi nad ten skuteczniejszy, żeby ta komisja była specialiter przywiązana po powinności każdego wojewody w swem województwie [...] żeby każde województwo miało swoje sub presentia wojewody złożone z czterech deputatów, in praesentia marszałka sejmikowego [...] żeby ci czterej deputaci componentes consilium palatinale, każdy z nich do osobliwej należał repartycji”, S. Leszczyński, Głos wolny wolność ubezpieczający, Kra-
} 
lokalnego szczebla administracji państwowej nie występują w pracach Stanisława Konarskiego oraz przedstawicieli Familii Czartoryskich ${ }^{98}$.

W okresie stanisławowskim zagadnienie organizacji zarządu państwowego doczekało się pogłębionej refleksji w pracy Antoniego Popławskiego, na zbieżność postulatów którego oraz przemyśleń Leszczyńskiego zwraca uwagę Jerzy Malec $^{99}$. W dwunastej części traktatu O porządku po województwach postulował on powołanie komisji wojewódzkich na czele $\mathrm{z}$ dożywotnim wojewodą ${ }^{100}$. W zakresie kompetencyjnym komisji miały się mieścić: „domowy porządek, co pożyteczniejszego wprowadzić albo już wprowadzanego do większej przywieść doskonałości”, układanie projektów „do bezpieczeństwa, wygody i porządku służące”, podniesienie „Z obrzydliwego nierządu” wsi, miasteczek i miast, rozwój handlu i rolnictwa, budowa manufaktur oraz sieci komunikacyjnej, zapewnienie kupcom bezpieczeństwa osobistego ${ }^{101}$. Uwagi dotyczące tworzenia administracji terenowej poczynił kuchmistrz litewski Michał Wielhorski, opowiadający się za wprowadzeniem wojewódzkich komisji, do których obowiązków należałby „porządek całego województwa”, w tym nadzór za szkolnictwem i ujednolicenie miar i wag ${ }^{102}$.

Nie można wykluczyć, że do omawianych wyżej traktatów nawiązywał autor Projektu formy rządu narodu polskiego, który ukazał się przed 1789 r. i zawierał postulat utworzenia rad wojewódzkich, na czele $\mathrm{z}$ wojewodami, o szerokich prerogatywach administracyjno-sądowych, składających się z reprezentantów szlachty i miast ${ }^{103}$.

Jak można przypuszczać, owocem pracy Deputacji do ukształtowania formy rządu był projekt pt. Komisje wojewódzkie. Przewidywał on, że składające się z 16 komisarzy komisje miały być podporządkowane instytucjom centralnym i przekazywać projekty w zakresie gospodarki i administracji. Komisje były pozbawiane możliwości stanowienia prawa i wydawania zarządzeń. Do ich funkcji należał tradycyjny zestaw rozwiązań z zakresu policystyki w kwestii poprawy stanu komunikacji, miar i wag, bezpieczeństwa wewnętrznego, a nawet wymiaru sprawiedliwości, aż po sprawy cywilno-wojskowe ${ }^{104}$.

ków 1858, s. 52-53; zob. tė̇: J. Malec, O recenzji Wacława Uruszczaka uwag kilka, „Czasopismo Prawno-Historyczne” 41, 1989, z. 1, s. 214; idem, Polska myśl administracyjna..., s. 35.

${ }_{98}$ J. Malec, Polska myśl administracyjna..., s. 45, 47-48.

${ }^{99}$ Ibidem, s. 60.

100 A. Popławski, Zbiór niektórych materii politycznych, Warszawa 1774, s. 265-266.

101 Ibidem, s. 266, 268-271.

102 M. Wielhorski, O przywróceniu dawnego rządu według pierwiastkowych Rzeczypospolitej ustaw, [b.m.w.] 1775, s. 151-153; J. Malec, Polska myśl administracyjna..., s. 63-64.

${ }^{103}$ J. Malec, Polska myśl administracyjna..., s. 122-124.

${ }^{104}$ Ibidem, s. 125-126. 


\section{Kilka uwag na temat stosunku szlachty do zmian ustrojowych}

Do ważnych elementów dyskusji politycznej w okresie Sejmu Wielkiego należało sięganie po obce przykłady ustrojowe. Anna Grześkowiak-Krwawicz zwraca uwagę na dość zawiły schemat myślenia i stosowania argumentów przez pisarzy i publicystów, przede wszystkim ze względu na punkty ich odniesienia, opierające się na analizie relacji pomiędzy poszczególnymi typami władzy oraz zakresem ich uprawnień, np. na eksponowaniu niebezpieczeństwa wzmocnienia władzy królewskiej oraz tronu dziedzicznego.

Dlatego też w Rzeczypospolitej obce wzory ustrojowe były interpretowane przez publicystykę przez pryzmat panujących układów i oczekiwań społecznych, a także istniejącego modelu ustrojowego. Odwoływano się do monarchicznej formy rządu, co prawda $z$ ukazaniem jej wad. Niemałe zainteresowanie wzbudzały rządy angielskie, a to przede wszystkim ze względu na wolność angielską. Z kolei rządy szwajcarski i amerykański - mimo pozytywnej oceny - nie stanowiły wzoru do naśladowania.

Tak więc odwołując się do doświadczeń obcych rządów, dążono do znalezienia potwierdzenia zalet własnej wizji ustrojowej, co wynikało z przeświadczenia o swoistości i doskonałości urządzeń ustrojowych w Rzeczypospolitej ${ }^{105}$. Poparciem tego zdania są wnioski Dariusza Rolnika, oparte na dogłębnej analizie pamiętników z czasów stanisławowskich, ujawniające niechęć szlachty do obcych modeli ustrojowych oraz odwołujące się do rozwiązań pochodzących $\mathrm{z}$ dawnych dziejów kraju ${ }^{106}$.

Można się zgodzić z twierdzeniem, że wzory ustrojowe Prus i Austrii były przenoszone do Rzeczypospolitej ${ }^{107}$. Powołuje się na nie starosta brański Michał Starzeński, próbując przekonać czytelników swoich pamiętników, że na podstawie nabytej w Wiedniu austriackiej literatury z dziedziny prawnoustrojowej przygotował projekt komisji cywilno-wojskowych ${ }^{108}$. Julian Ursyn Niemcewicz - przychylnie ustosunkowany do przemian dokonujących się we Francji - pozytywnie oceniał fakt powołania do życia zrębów administracji lokalnej, porównując dokonania sejmu z projektem „administracji prowincjonalnej” autorstwa Anne Roberta Jacques'a Turgota ${ }^{109}$.

\footnotetext{
${ }^{105}$ A. Grześkowiak-Krwawicz, op. cit., s. 13; G.L. Seidler, op. cit., s. 82-88, 91.

${ }^{106}$ D. Rolnik, Portret szlachty czasów stanisławowskich, epoki kryzysu, odrodzenia i upadku Rzeczypospolitej w pamiętnikach polskich, wyd. 2, Katowice 2011, s. 391-397.

107 G.L. Seidler, op. cit., s. 142.

${ }^{108}$ M. Starzeński, Na schyłku dni Rzeczypospolitej (1757-1795), wyd. H. Mościcki, Warszawa 1914, s. 74; A. Zahorski, op. cit., s. 25.

109 J.U. Niemcewicz, Pamiętniki czasów moich, t. 1, oprac. J. Dihm, [Warszawa] 1957, s. 278-279; Z. Libera, Sejm Czteroletni w oczach pamiętnikarzy, w: Sejm Czteroletni i jego tradycje..., s. 182.
} 
$\mathrm{Z}$ drugiej strony, jak można sadzić, przenikanie podobnych treści nie zawsze budziło podziw zwolenników republikańskiego ustroju: raczej oddziaływało odwrotnie. Na obawy przed projektem komisji porządkowych kojarzonych ze wzmocnieniem władzy wykonawczej wskazuje Emanuel Rostworowski. Nie okazywał zachwytu reformami w monarchii Habsburgów Szczęsny Potocki, nadmieniający w liście do Stanisława Małachowskiego: „aby z tego tak nam obrzydłe dyrektoriaty nie urosły”. Dalej z przerażeniem pisał do Stanisława Kostki: „te wojewódzkie komisje okrutnie mnie straszą. Od dyrektoriatu uciekam z Galicji, a boje się, aby te znowu nie przypomniały mi rzeczy nienawidzonej"110.

Można się więc domyślać, że właśnie z tych powodów autor podręcznika Początkowe prawidła policji ogólnej (1792), obeznany z literaturą europejską oraz pracą Nicolasa de La Mare Traité de la police, a także świadomy republikańskich nastrojów w „narodzie”, wolał pozostać anonimowym ${ }^{111}$.

Warto przytoczyć trafne spostrzeżenie Emanuela Rostworowskiego, że zabierając się za przygotowanie projektu formy rządu, Ignacy Potocki aktywnie korzystał ze zbiorów królewskiej biblioteki, obficie zaopatrzonej w liczne dzieła francuskie. Niemniej jednak unikał powoływania się na treść francuskiej Deklaracji praw człowieka i obywatela, podkreślając, że Deputacja „rozpoczyna [...] od deklaracji praw, lecz nie praw człowieka (de l'homme), ale szlachcica (du gentilhomme)"112.

\section{Prywatne ksiegozbiory i czytelnictwo}

Publikacje traktujące o sporach na temat rozwiązań ustrojowych lub zmierzające do ustalenia skali oddziaływań europejskiej myśli oświeceniowej nie uwzględniają tak słabo uchwytnego wątku, jakim było przenikanie dzieł nauki policji do księgozbiorów w Rzeczypospolitej. Jerzy Malec zauważa zachowanie prac Nicolasa Delamare'a, Johanna-Heinricha von Justiego lub Josepha von Sonnenfelsa w księgozbiorach Warszawy, Poznania, Wrocławia, Katowic i Krakowa. Dzieła te posiadali w swoich bibliotekach Stanisław Lubomirski oraz Potoccy. Andrzej Zahorski zwraca uwagę na to, że popularna w Polsce Wielka encyklopedia francuska (Encyclopédie, ou dictionnaire raisonné des sciences, des arts et des métiers) Denisa Diderota omawiała prace Delamare'a w haśle police ${ }^{113}$. Zresztą kolejne potwierdzenie stanowią ślady obecności Encyclopédie w zbiorach magnackich, posiadali ją np. Sapiehowie w Dereczynie ${ }^{114}$.

\footnotetext{
${ }^{110}$ E. Rostworowski, Ostatni król Rzeczypospolitej..., s. 193-194.

${ }^{111}$ J. Malec, Polska myśl administracyjna..., s. 134.

112 W. Kalinka, Sejm Czteroletni... (1895), t. 1, cz. 2, s. 691, 693; E. Rostworowski, Ostatni król Rzeczypospolitej..., s. 173-174; A. Lityński, op. cit., s. 71-72.

${ }^{113}$ A. Zahorski, op. cit., s. 24; J. Malec, Polska myśl administracyjna..., s. 142.

${ }^{114}$ L. Kowkiel, Prywatne ksiegozbiory na Grodzieńszczyźnie w pierwszej połowie XIX wieku, Kraków 2005, s. 121.
} 
Nie ulega wątpliwości, że kolejnym zabiegiem, który mógłby pozwolić na zbadanie niniejszego zagadnienia, jest próba dotarcia do zachowanych egzemplarzy dzieł ówczesnej policystyki w celu zbadania ich proweniencji.

Na okres oświecenia przypada nasilenie się procesu tworzenia bibliotek, których zawartość mogłaby stanowić interesującą wskazówkę dla lepszego zrozumienia stanu ówczesnej umysłowości. Jednak w ramach jednego artykułu nie jest możliwe wypełnienie tak obszernej luki z zakresu dziejów książki, w tym przeprowadzenie rekonstrukcji istniejących wówczas księgozbiorów domowych, zbadanie procesu gromadzenia zbiorów, a tym bardziej ustalenie proweniencji na podstawie zachowanych egzemplarzy. Zarówno prozaiczny brak tradycji gromadzenia księgozbiorów ${ }^{115}$, nikły stan zachowania ówczesnych kolekcji książek w wyniku zawirowań dziejowych, spore rozproszenie oraz niekompletność dokumentacji zbiorów bibliotecznych ${ }^{116}$, jak i fakt różnorodnych zainteresowań czytelniczych komplikują wyjaśnienie tego zagadnienia. Ze względu na swój charakter literatura z zakresu nauki policji, w odróżnieniu np. od literatury pięknej, nie należała w badanym okresie do najbardziej poczytnych. Toteż nie wszyscy właściciele bibliotek kupowali książki z dziedziny myśli administracyjnej i prawnoustrojowej.

Do czynników utrudniających rozpoznanie tematu należą liczne przemieszczenia i rozproszenia oświeceniowych księgozbiorów. Na przykład biblioteka Radziwiłłów z Nieświeża wskutek wywiezienia do Rosji w 1772 r. uległa zatraceniu $^{117}$, w różnym czasie rodowe siedziby opuściły słynne biblioteki Sapiehów w Dereczynie, Chreptowiczów w Szczorsach, Niemcewiczów w Skokach, podziałom i przemieszczeniu uległy sięgające swymi początkami oświecenia kolekcje książek Strawińskich w Nakryszkach, Śliźniów w Dziewiątkowiczach, Potockich w Wysokim Litewskim, Sołtanów w Zdzięciole ${ }^{118}$. W badaniu czytelnictwa nie bez znaczenia pozostaje fakt, że nie wszystkie oświeceniowe biblioteki miały charakter publiczny, co ograniczało dostęp do ich osób zainteresowanych. Wreszcie niezadowalający stopień alfabetyzacji społeczeństwa, w tym pewnej części szlachty czy mieszczaństwa, jeszcze bardziej zawężał krąg odbiorców. Ustalenie faktów posiadania prac dotyczących zagadnień prawnoustrojowych należy do zabiegów czasochłonnych nie tylko ze względu na stan zachowania bibliotek, lecz również biorąc pod uwagę niezbyt staranną dokumentację domowych kolekcji książek oraz

${ }^{115}$ P. Köhler, Biblioteka naukowa Józefa Jundziłła (1794-1877), „Kwartalnik Historii Nauki i Techniki" 42, 1997, nr 3-4, s. 63.

${ }^{116}$ U. Paszkiewicz, Wybrane problemy dokumentacji zbiorów bibliotecznych na wschodnich ziemiach Rzeczypospolitej do 1939 roku, „Roczniki Biblioteczne” 45, 2001, s. 55-89; eadem, $Z$ warsztatu badań proweniencyjnych. Wybrane znaki własnościowe księgozbiorów prywatnych na wschodnich ziemiach Rzeczypospolitej, „Roczniki Biblioteczne” 48, 2004 [2005], s. 107-126.

117 Z. Goliński, Biblioteki i czytelnictwo, w: Słownik literatury polskiego Oświecenia, red. T. Kostkiewiczowa, Wrocław 1996, s. 31.

${ }^{118}$ L. Kowkiel, op. cit., s. 39-40, 132-158. 
trudności w odtwarzaniu rzeczywistych opisów bibliograficznych na podstawie ówczesnych inwentarzy i katalogów.

W katalogach prywatnych księgozbiorów XVIII i XIX w. z interesującej nas tematyki znaczną grupę prac stanowią konstytucje i diariusze sejmowe, statuty litewskie i traktaty polityczne. W inwentarzu biblioteki Eustachego Kajetana Sapiehy, założonej przez jego dziadka Aleksandra Michała Sapiehę ${ }^{119}$, spotykamy Prospekt Zbioru Statutów, ustaw i konstytucji (Wilno 1789), Do Najjaśniejszych stanów sejmujących przed poprawa rządu krajowego (1789) ${ }^{120}$, a w księgozbiorze Wacława Seweryna Rzewuskiego, syna hetmana polnego koronnego Seweryna Rzewuskiego, diariusz sejmu grodzieńskiego z 1784 r. oraz Statut Wielkiego Księstwa Litewskiego $(1744)^{121}$.

Oprócz różnorodnych materiałów sejmowych z okresu Sejmu Czteroletniego w zbiorze Karola Niemcewicza znajdowała się praca angielskiego myśliciela Thomasa Paine'a ${ }^{122}$. Inwentarz biblioteki Hipolita Korsaka ${ }^{123}$ notuje z kolei O prawie przyrodzonym Waleriana Stroynowskiego (1785) oraz O sukcesji tronu Seweryna Rzewuskiego ${ }^{124}$.

Analiza księgozbiorów wskazuje, że tworzyły je zarówno polskie, jak i zachodnioeuropejskie prace. Na przykład w spisanym w 1814 r. inwentarzu książek należących do Michała Ogińskiego wzmiankuje się prace: Duch czyli treść praw przez Pana Montesquieu ${ }^{125}$ oraz O uszczęśliwieniu narodu Józefa Puszeta ${ }^{126}$. Tomasz Bułhak ${ }^{127}$ był zaś w posiadaniu prac Godfryda Lengnicha ${ }^{128}$ i Stanisława Staszica Przestróg dla Polski z teraźniejszych politycznych Europy związków y z praw natury wypadajacych (1790).

${ }^{119}$ J. Wojakowski, Ksiegozbiory Eustachego Kajetana Sapiehy (1797-1860) i Wacława Seweryna Rzewuskiego (1785-1831), Warszawa 1996, s. 45.

${ }^{120}$ M. Świniarski, Do Najjaśniejszych stanów sejmujących przed poprawą rządu krajowego, w: Materiały do dziejów Sejmu Czteroletniego, t. 2, wyd. i oprac. J. Woliński, J. Michalski, E. Rostworowski, Wrocław 1959, s. 32-58.

${ }^{121}$ J. Wojakowski, op. cit., s. 67.

122 Rosyjskie Państwowe Archiwum Historyczne, f. 384, op. 15, nr 1282, k. 21v; T. Paine, Recueil des divers écrits de Thomas Paine [...] sur la politique et la législation, faisant suite aux autres ouvrages du même auteur, intitulés: Les droits de l’homme et Le sens commun, tłum. $\mathrm{z}$ ang., Paris, F. Buisson 1793.

${ }^{123}$ NAHB, f. 333, op. 24, nr 154, k. 155-157.

${ }^{124}$ Seweryna Rzewuskiego hetmana polnego koronnego O sukcesyi tronu w Polszcze rzecz krótka, Amsterdam [Drezno, a może Kraków?] 1789; [Warszawa] 1789 - znane dwa wydania. W przypadku pracy Hieronima Stroynowskiego inwentarz księgozbioru wymienia tytuł O prawie przyrodzonym, chodzi prawdopodobnie o dzieło pt. Nauka prawa przyrodzonego, politycznego, ekonomiki polityczney, y prawa narodów, Wilno 1785.

${ }^{125}$ NAHB, f. 458 , op. 1 , nr 2, k. 886v.

${ }^{126}$ Ibidem, k. 887v; J. Puszet, O uszczęśliwieniu narodów, Warszawa 1788; J. Malec, Polska myśl administracyjna..., s. 113-115, 190.

${ }^{127}$ NAHB, f. 31, op. 2, nr 175, k. 158v-159.

${ }^{128}$ G. Lengnich, Ius publicum Regni Poloniae, t. 1-2, Gedani 1765-1766. 
Księgozbiór Ignacego Potockiego prezentuje różnorodne zainteresowania jego właściciela. Wskazują na to prace autorstwa Franciszka Salezego Jezierskiego, Davida Hume’a, Étienne’a Bonnota de Condillac, Johna Locke’a, Jana Jakuba Rousseau. Potocki posiadał liczne druki urzędowe, w tym komisji porządkowej województwa lubelskiego z 1794 r., a także był oczytany w literaturze francuskiej w zakresie szkolnictwa ${ }^{129}$. Emanuel Rostworowski pisze, nie podając jednak źródła, że Ignacy Potocki w trakcie prac nad formą rządu w $1789 \mathrm{r}$. sięgał po francuskie gazety ${ }^{130}$.

Sporą różnorodnością charakteryzował się księgozbiór Joachima Litawora Chreptowicza. Należały do niego: „zbiór konstytucji koronnych”131, Seryarz projektów do prawa i innych różnych pism, uwagi, myśli patryotycznych, żądań, województw ziem i powiatów pomiędzy seymem a seymem na rok $1785^{132}$, Stanisława Staszica Uwagi nad życiem Jana Zamoyskiego (1787) ${ }^{133}$, Gotfryda Lengnicha Ius publicum Regni Poloniae (1746) ${ }^{134}$, Nauka prawa przyrodzonego Hieronima Stroynowskiego (1785) ${ }^{135}$, w dziale „Rękopisma” zaś pod hasłem „Polityka” zarejestrowano m.in. Głos wolny wolność ubezpieczajacy (1733) ${ }^{136}$, Tłumaczenie uwag nad forma rząów Jeana-Josepha Mouniera (1789) ${ }^{137}$.

W księgozbiorze Kazimierza Wołłowicza (spis z 1831 r.) zgromadzone były prace Jana Jakuba Rousseau, Rocha-Antoine'a de Pellissery L'administration politique de Colbert ${ }^{138}$ oraz Anatomia Rzeczypospolitej Polskiej ${ }^{139}$ Stefana Gar-

129 J. Rudnicka, Biblioteka Ignacego Potockiego, Wrocław 1953, s. 59-63, 83.

${ }^{130}$ Eadem, Czytelnicy w bibliotece warszawskiej marszałka Lubomirskiego, „Przegląd Biblioteczny” 1958, nr 2, s. 207-213; E. Rostworowski, Ostatni król Rzeczypospolitej..., s. 173.

${ }^{131}$ B. Jagiellońska, rkps 2721, Opis bibliograficzny książek w prywatnej bibliotece Adama hr Chreptowicza w Szczorsach znajdującej się ( $\mathrm{z}$ wyłączeniem dzieł cudzoziemskich). R. 1826 przez Jana G. Styczyńskiego, k. 95v.

132 Zebranie biblioteki polskiej, 1812, k. 109; Narodowa Biblioteka Ukrainy im. W.I. Wernadskiego, Instytut Rękopisu, rkps I, 6085 (publikacja elektroniczna), w: Книжное собрание рода Хрептовичей [Электронный ресурс] Нац. б-ка Украины им. В.И. Вернадского, Нац. б-ка Беларуси, Нац. комис. Респ. Беларусь по делам ЮНЕСКО, oprac. Л.Г. Кирюхина, Л.А. Дубровина, red. Л.Г. Кирюхина, Т.И. Рощина, Минск 2009; Seryarz projektów do prawa i innych różnych pism, uwagi, myśli patryotycznych, żądań, woiewództw ziem i powiatów pomiędzy seymem a seymem od senatorów, posłów y gorliwych patryotów formowanych roku pierwszego 1785, t. 1-2, [b.m.w.] 1785; J. Malec, Polska myśl administracyjna..., s. 79-80.

${ }^{133}$ Zebranie biblioteki polskiej..., k. 83.

${ }^{134}$ Ibidem, k. 101.

135 Ibidem, k. 85; H. Stroynowski, Nauka prawa przyrodzonego, politycznego, ekonomiki polityczney, y prawa narodów, Wilno 1785.

136 Zebranie biblioteki polskiej..., k. 310.

${ }^{137}$ Ibidem, k. 313; J.-J. Mounier, Considérations sur les gouvernements, et principalement sur celui qui convient à la France, Versailles 1789.

${ }^{138}$ R.-A. de Pellissery, L’Administration politique de Colbert: ouvrage qui par son érudition, ses principes économiques, calculs politiques \&́c. peut servir de repertoire universel des connoissances nécessaires à des administrateurs, Amsterdam-Lepzig 1776.

${ }^{139}$ S. Garczyński, Anatomia Rzeczypospolitej Polskiej synom ojczyzny ku przestrodze i poprawie tego, co z kluby wypadło, mianowicie o sposobach zamnożenia Polskę ludem pospolitym, konserwowania 
czyńskiego, postulującego reformy społeczno-gospodarcze ${ }^{140}$, a także Monteskiuszowski Duch czyli treść praw (1777), Nauka prawa przyrodzonego fizjokraty Hieronima Stroynowskiego oraz „Dziennik Handlowy”141.

Interesująco przedstawia się również biblioteka króla Stanisława Augusta, zawierająca traktaty społeczno-polityczne, prace myślicieli, prawników i filozofów: Hugona Grocjusza, Cesarego Beccarii, Christiana Wolffa ${ }^{142}$, Ferdynanda Naxa ${ }^{143}$, Michała Ossowskiego ${ }^{144}$, Wincentego Skrzetuskiego ${ }^{145}$ oraz Ius publicum Regni Poloniae (1765-1766) i Ius publicum Prussiae Polonae (Gdańsk 1758) Gotfryda Lengnicha ${ }^{146}$, a także Wielką encyklopedię francuską ${ }^{147}$.

W 1798 r. przygotowano inwentarz dóbr Kotłowo położonych w województwie nowogródzkim. Ich właścicielem był Franciszek Woyniłłowicz, który - co należy wyraźnie podkreślić - pełnił funkcję komisarza cywilno-wojskowego powiatu słonimskiego ${ }^{148}$. Inwentarz oprócz tradycyjnego spisania rzeczy ruchomych (ubrań bądź sprzętu gospodarczego) zawierał wykaz książek z domowej biblioteki ${ }^{149}$, w tym literaturę prawnoustrojową $\mathrm{w}$ języku polskim, egzemplarz Statutu Wielkiego Księstwa Litewskiego z 1588 r., konstytucje i mowy sejmowe, Uwagi nad życiem Jana Zamoyskiego Stanisława Staszica, Uwagi nad rzadem polskim Jana Jakuba Rousseau. Na szczególną uwagę zasługuje zapis dotyczący książki w języku francuskim, której tytuł był podany w sposób następujący „Administracja francuska, tomów trzy”. Można jedynie przypuszczać, że pisarz w taki sposób zanotował dzieło Nicolasa de La Mare Traité de la police ${ }^{150}$. Zestawienie

dziatwy wiejskiej, przez niedostatek i niewygody marnie ginacej, i wprowadzenia handlów i manufaktur zagranicznych, Berlin 1742.

${ }_{140}$ W. Stankiewicz, Historia myśli ekonomicznej, Warszawa 1983, s. 124-126.

${ }^{141}$ Rosyjskie Państwowe Archiwum Historyczne, f. 384, op. 15, nr 460, k. 161v; NAHB, f. 31, op. 2, nr 59, k. 185v, 190-191.

${ }_{142}$ Ch. Wolff, Jus Naturae, Methodo, Scientifica Pertractatum, t. 1-8, Francofurti-Lipsiae 1740-1748.

${ }^{143}$ F. Nax, Uwagi nad uwagami, czyli obserwacje nad książka pod tytułem: Uwagi nad życiem Jana Zamoyskiego kanclerza i hetmana wielkiego koronnego, Warszawa 1789; J. Malec, Polska myśl administracyjna..., s. 115.

${ }_{144}$ M. Ossowski, Uwagi nad projektem o pomnożeniu dochodów publicznych, [Warszawa 1789].

${ }^{145}$ W. Skrzetuski, Prawo polityczne narodu polskiego, t. 1-2, Warszawa 1782-1784; J. Malec, Polska myśl administracyjna..., s. 76-77, 147-148.

146 Biblioteka Stanisława Augusta na zamku warszawskim, oprac. J. Rudnicka, Wrocław 1988, s. 67, $86,121,142$.

${ }^{147}$ Ibidem, s. 16, 85, 295, 314.

${ }^{148}$ Urzędnicy centralni i dostojnicy Wielkiego Księstwa Litewskiego XIV-XVIII wieku, oprac. H. Lulewicz, A. Rachuba, Kórnik 1994, s. 51.

${ }^{149}$ Акты Виленской археографической комиссии, t. 38, Вильно 1914, s. 444-447; С. Куль-Сяльверстава, Палітька, культура, асоба. Нарысы па гісторьі культуры Беларусі, Гродна 2012, http://pawet.net/library/history/bel_history/kul/10/Палітыка._Культура._Асоба..html\#_ Toc3496758 (dostęp: 8 II 2015).

${ }^{150}$ N. de La Mare, Traité de la police, où l'on trouvera l'histoire de son établissement, les fonctions et les prérogatives de ses magistrats; toutes les loix et tous les réglemens qui la concernent, t. 1-4, Paris 1705-1738. 
tych wiadomości - właściciel ziemski i komisarz porządkowy posiadający jak można się domyślać cenne dzieło policystyki - nie może nie zwracać uwagi, choć ze względu na jednostkowy charakter nie pozwala na generalizację.

Zmierzając do podsumowania, należałoby wspomnieć o tym, że źródłem wiedzy o europejskich przekształceniach administracyjnych były również podróże oraz studia, np. w katedrze umiejętności politycznych Uniwersytetu we Lwowie, gdzie nauczano ekonomii, kameralistyki i „policji”"151. Jest to więc kolejny obszerny wątek, zasługujący na dogłębne zbadanie.

\section{Konstytucja sejmowa: między myślą a tradycją}

Analiza konstytucji sejmowej stanowiącej ważne źródło prawa pozwala na zobrazowanie obecnych tam wątków ówczesnych stanowisk ekonomicznych i filozoficznoprawnych. Ujmując sprawę z nieco innej perspektywy, ukazuje refleksje prawnoustrojowe i ekonomiczne wyzyskiwane przez ustawodawców, co umożliwia tym samym lepsze zorientowanie się w porządku światopoglądowym ówczesnych elit rządzących.

Przypomnijmy, że jesienią 1789 r. dyskusja nad kształtami zrębów władzy wykonawczej w terenie wyraźnie się ożywiła. Trudno się nie zgodzić z poglądem, że prace nad ostatecznym kształtem konstytucji nie ograniczały się do teoretycznych rozważań nad wniesioną materią. Według diariusza na forum sejmowym posłowie wysuwali liczne projekty administracji lokalnej, tok debaty skłaniał zaś ku konieczności uwzględnienia doświadczeń komisji powiatowych działających latem i jesienią tegoż roku.

Ostateczny kształt uchwalonej konstytucji oscylował wokół kwestii realizacji aukcji wojska, na którą składały się liczne zadania nowo powstałych komisji, m.in. pobór rekruta, kwaterunek, aprowizacja i urządzenia magazynów, dostarczanie podwód, wydatkowanie środków finansowych dla potrzeb wojska, rozstrzyganie kwestii szkód i wzajemnych krzywd między wojskiem a ludnością cywilną. Realizacja tak szerokiego spektrum spraw wiązała się ze zwiększeniem wpływów budżetowych. Toteż rozbudowa administracji lokalnej stanowiła niezbędny, wręcz brakujący instrument polityki skarbowej i finansowej państwa w terenie.

Pomimo przesiąknięcia konstytucji utylitarnymi treściami jej autorzy nie uniknęli odniesień do ówczesnych prądów ekonomicznych, w swoisty sposób dokonując interpretacji idei merkantylizmu i fizjokratyzmu. Już pierwszy akapit konstytucji, traktujący o rządzie, który miał dążyć do „uskutecznienia tych szczęśliwości”, dowodzi jeśli nie znajomości myśli oświeceniowej przez posłów, to przynajmniej zbieżności z postulatami epoki, przede wszystkim

${ }^{151}$ Zob. też J. Malec, Polska myśl administracyjna..., s. 142. 
z hasłami eudajmonizmu państwowego, mającego zapewnić poddanym szczęście i dobrobyt ${ }^{152}$.

Przykład merkantylistycznej wizji mogłyby stanowić hasła równomiernego rozwoju rolnictwa, handlu i rzemiosła. Za tym przemawia wzmianka, że „produkta ziemne, rękodzieła i handel, są istotnym każdego państwa bogactwem"153. W konstytucji zresztą spotykamy specyficzne rozumienie roli form przemysłowych. Autorzy żywili przeświadczenie, że nastawienie na produkcję mundurów, broni i innych niezbędnych dla funkcjonowania armii artykułów zachęci do „sposobności zakładania i utrzymywania fabryk krajowych" ${ }^{\text {"154. W }}$. tym przypadku mamy do czynienia $\mathrm{z}$ kameralistycznym hasłem, traktującym armię jako czynnik zakładania nowych przedsiębiorstw, wzrostu siły roboczej oraz zwiększenia dochodów państwa ${ }^{155}$. Zresztą podobne głosy o wykorzystywaniu zdolności produkcyjnych w celu zwiększenia dochodów państwa padały z sejmowej mównicy. Na przykład 24 października 1788 r. poseł Sieradzki zaznaczał, że „będzie wojsko, pomnoży się krajowa konsumpcja, powiększą się fabryki, podwoją się tym samym nasze dochody"156.

Autorzy konstytucji sygnalizowali konieczność prowadzenia spisów i metryk ludności, usprawnienia arterii komunikacyjnych, dostrzegania prawidłowości miar i wag, zwalczania ubóstwa oraz zlustrowania szpitali, przestrzegania bezpieczeństwa i porządku publicznego. Większość z tych postulatów w przypadku konstytucji miała wydźwięk utylitarny.

Niemniej jednak różne zagadnienia nurtujące ówczesną myśl społeczną, np. zreformowanie gospodarki miast, przeznaczenie wpływów podatkowych na inwestycje, wydawały się być drugorzędne lub w ogóle niedostrzegane przez autorów. Poza tym brakuje w konstytucji właściwych dla kameralistyki haseł zniesienia poddaństwa oraz zapewnienia chłopom opieki prawnej.

Ze zrozumiałych przyczyn stanowiące główny filar gospodarki rolnictwo nie mogło być pominięte przez ustawodawców, zalecających władzom terenowym skupienie się na ułożeniu „projektów gospodarstwa kompozycji gruntów swego województwa” oraz zachęcaniu właścicieli ziemskich do „polepszenia reguł rolnictwa" poprzez udzielanie porad w kwestiach rolniczych i sposobów pomnażania produktu zbożowego ${ }^{157}$. Jak można sądzić, mamy tu do czynienia z popularnymi

152 „Rząd dobry gdy jest jedyną całości, ozdoby i pożytków krajowych zasadą, ażeby przeto do uskutecznienia tych szczęśliwości dążącemu powszechnemu ustaw sejmu niniejszego zamiarowi, odpowiadały i pomagały", Komisje wojewódzkie i powiatowe w Wielkim Księstwie Litewskim..., s. 136; zob. J. Gordziejew, op. cit., s. 25.

${ }^{153}$ Komisje wojewódzkie i powiatowe $w$ Wielkim Księstwie Litewskim..., s. 141; B. Leśnodorski, op. cit., s. 95, 97.

${ }^{154}$ Komisje wojewódzkie i powiatowe w Wielkim Księstwie Litewskim..., s. 142.

${ }^{155}$ E. Lipiński, op. cit., s. 419.

${ }^{156}$ Dyaryusz Seymu Ordynaryinego..., t. 1, cz. 1, s. 126.

${ }^{157}$ E. Lipiński, op. cit., s. 475-476. 
wówczas ideami zaprowadzenia nowych metod produkcji rolnej, rozwoju agrotechniki i agrokultury ${ }^{158}$, nawiązującymi do myśli fizjokratycznej, traktującej ziemię i jej płody jako podstawę bogactwa krajowego.

W konstytucji spotykamy postulat rozwoju „różnych minerów”, występujący u fizjokratów faworyzujących górnictwo zajmujące się wydobyciem bogactw naturalnych. Oprócz tego konstytucja odwołuje się do hasła szerzenia oświaty jako elementu ówczesnego życia umysłowego poprzez zakładanie wiejskich szkół parafialnych „dla oświecenia ciemnej prostoty poddaństwa"159.

\section{Komisje porządkowe a tradycje sejmikowej samorządności}

Pisząc o reorganizacji aparatu administracyjnego, Hugo Kołłątaj w szóstym liście Listów Anonima, datowanym 2 listopada 1788 r., proponował wskrzeszenie sejmików gospodarskich, które miały stanowić organ nadzorujący prace nowo powstałych urzędów w terenie: „Sejmiki gospodarskie zarzucone dla powszechnego nierządu jeżeli kiedy mogły być przydatne tedy za ustanowieniem Trwałego Sejmu zdają się być koniecznie potrzebne"160.

Uwagi o podobnej treści znajdujemy w pracy Antoniego Popławskiego, który opierał swoją wizję zarządu lokalnego na sejmikach gospodarskich jako organach prawotwórczych oraz komisjach wojewódzkich jako egzekutywie terenowej, które określał jako „dobrej ekonomii komisje”. Co ciekawe, ustanowieniu tych komisji - jego zdaniem - miał sprzyjać „dawny przykład i zwyczaj odprawiania tym końcem gospodarskich sejmików”. Kontynuując swoje rozważania, Popławski podkreślał, że realizacja tego projektu „nie jest bynajmniej rzeczą nową", komisarzy zasiadających wraz z wojewodą miał zaś obierać sejmik spośród ziemskich urzędników ${ }^{161}$.

Niniejsze materiały wyraźnie ukazują ciążenie myśli społecznej do tradycyjnych, rodzimych rozwiązań ustrojowych, na celowość wykorzystania których wskazuje analiza stanowisk historiograficznych z końca XIX w. Na przykład Walerian Kalinka był przekonany, że komisje porządkowe „zastąpiły skutecznie dawne sejmiki gospodarskie". Tadeusz Korzon nieco rozbudował ten wątek, łącząc powstanie komisji porządkowych z brakiem wykonawczych ogniw zarządu lokalnego: „województwo ziemia i powiat ze swoim nietykalnym samorządem nie

\footnotetext{
${ }^{158}$ Komisje wojewódzkie i powiatowe w Wielkim Księstwie Litewskim..., s. 138.

${ }^{159}$ Ibidem, s. 142.

${ }^{160}$ H. Kołłątaj, Do Stanisława Małachowskiego referendarza koronnego, marszałka sejmowego i konfederacji generalnej Anonima listów kilka, cz. 2, [b.m.w.] 1788, s. 180-181, 229, 233-234; J. Malec, Polska myśl administracyjna..., s. 104, 154.

${ }^{161}$ A. Popławski, op. cit., s. 266-268; J. Malec, Polska myśl administracyjna..., s. 153.
} 
posiadały żadnego stałego organu administracyjnego, przynajmniej w XVIII w. prócz sejmiku gospodarczego"162.

Oczywiście do niniejszych wniosków należałoby się odnieść z pewną rezerwą. Można się zgodzić co do pokrywania się funkcjonalno-kompetencyjnych aspektów działalności sejmików gospodarczych oraz komisji porządkowych. Niemniej jednak nie ulega wątpliwości, że działalność komisji charakteryzowała się szerszym, bardziej kompleksowym - jak na miarę czasu - zakresem zadaniowym ${ }^{163}$. Jak można sądzić, zbieżności kompetencyjne tych organów dały podstawę Adamowi Lityńskiemu do wysnucia wniosku o ścisłym związku sejmików i komisji porządkowych oraz o tym, że komisje „w pewnym sensie spełniały funkcje organów sejmików"164.

Skarbowo-finansowo-wojskowy nurt samorządu szlacheckiego wykształcił się w XVII w. Wobec upadku znaczenia władzy centralnej oraz urzędu starosty sejmiki przejmowały zarząd $\mathrm{w}$ terenie, podejmując decyzje leżące $\mathrm{w}$ gestii sejmu ${ }^{165}$. Przedmiotem prac sejmików były kwestie wojskowe oraz uchwały podatkowe, a także wyznaczenie komisarzy do nadzoru miar objętości, dbanie o porządek i bezpieczeństwo wewnętrzne, zaciąg chorągwi i zwoływanie szlachty na pospolite ruszenie, zapomogi poszkodowanym przez pożary oraz kwestię oświaty młodzieży szlacheckiego pochodzenia ${ }^{166}$.

Kończąc rozważania o reformach sejmików w drugiej połowie XVIII w., Adam Lityński podkreślił, że po 1717 r. samorząd szlachecki był pozbawiony dużej części uprawnień skarbowo-wojskowych. Uściślając tę uwagę, trzeba zauważyć, że krok ten był podyktowany rezygnacją z praktyki każdorazowego uchwalania

162 T. Korzon, Wewnętrzne dzieje Polski za Stanisława Augusta..., t. 5, s. 196.

${ }^{163}$ Z. Kaczmarczyk, B. Leśnodorski, Historia państwa i prawa Polski, red. J. Bardach, t. 2: Od połowy XV wieku do r. 1795, wyd. 4, Warszawa 1971, s. 539.

${ }^{164}$ A. Lityński, op. cit., s. 187, 192.

${ }^{165}$ A. Rachuba, Wielkie Księstwo Litewskie w systemie parlamentarnym Rzeczypospolitej w latach 1569-1763, Warszawa 2002, s. 76, 208-212.

166 A. Lityński, op. cit., s. 38-39; W. Kriegseisen, Sejmiki Rzeczypospolitej szlacheckiej w XVII i XVIII wieku, Warszawa 1991, s. 86-97, 241-252; A.B. Zakrzewski, Sejmiki Wielkiego Księstwa Litewskiego XVI-XVIII w. Ustrój i funkcjonowanie - sejmik trocki, Warszawa 2000, s. 191-206; M. Zwierzykowski, Funkcjonowanie samorządu sejmikowego województw poznańskiego i kaliskiego od XVI do XVIII wieku, w: Sejmik wielkopolski, red. A. Kamieński, Jarocin-Szczecin 2008, s. 19-33; A. Radaman, Samorząd sejmikowy w powiatach województwa nowogródzkiego Wielkiego Księstwa Litewskiego w latach 1565-1632, w: Praktyka życia publicznego w Rzeczypospolitej Obojga Narodów w XVI-XVIII wieku. Materiały pokonferencyjne XVIII Komisji Lituanistycznej przy KNH PAN, red. U. Augustyniak, A.B. Zakrzewski, Warszawa 2010, s. 62-63; R. Jurgaitis, Funkcjonowanie sejmiku wileńskiego w latach 1717-1795. Między szlacheckim parlamentaryzmem a samorządem, w: Praktyka życia publicznego..., s. 46-51; D. Konieczna, Ustrój i funkcjonowanie sejmiku brzesko-litewskiego w latach 1565-1763, Warszawa 2013, s. 93-101, 133-147, 154-157; А. Мацук, Соймікі Полацкага ваяводства у панаванне Аўгуста III, „Вестник Полоцкого Государственного Университета. Серия А” 2011, nr 9, s. 32-39. 
podatków oraz dążeniem do uniezależnienia wojska od pośrednictwa sejmików. Tymczasem negatywnym skutkiem tej decyzji było to, że w ciągu całego stulecia w ich miejsce nie wprowadzono żadnych skutecznych rozwiązań wykonawczych, a deklarowane ograniczenia samorządu szlacheckiego nie zawsze były przestrzegane. Bardziej restrykcyjny charakter miały ograniczenia zastosowane w drugiej połowie XVIII w., kiedy zakazano sejmikom podejmowania uchwał podatkowych oraz zniesiono skarby wojewódzkie i powiatowe ${ }^{167}$.

Jak można sądzić, decentralizacyjny model ustrojowy, o którego ewolucji zadecydowały względy natury obiektywnej, potrzeby podjęcia szybkiej decyzji, stanowił przykład sprawnego administrowania oraz umiejętności rządzenia ${ }^{168}$.

W tym przypadku nasuwa się pytanie, czy brak skutecznych organów wykonawczych w terenie w okresie Sejmu Czteroletniego nie stanowił czynnika wymuszającego konieczność powołania do życia instytucji zdolnych do reagowania w zaistniałej sytuacji oraz - jeśli można się pokusić o takie sformułowanie - do odwołania się do historycznie ukształtowanych wzorów zarządzania terenem? I czy komisje porządkowe jeśli nawet nie kontynuowały na drodze ewolucji, to nawiązywały do żywej tradycji pełnienia przez sejmiki funkcji egzekutywy lokalnej?

Oczywiście należy zwrócić uwagę na istotną różnicę natury ustrojowej. Sejmiki gospodarskie oraz sądy skarbowe były elementem zdecentralizowanego modelu zarządzania, ich kompetencje zaś były określane przez samorząd szlachecki.

Nowo powstałe organy władzy wykonawczej w terenie były ściśle powiązane $\mathrm{z}$ tradycyjnym podziałem terytorialnym państwa oraz uzależnione od lokalnej społeczności ze względu na instytucję wyborów kontrolowaną przez lokalną wspólnotę. Na przykład w odróżnieniu od Francji czy Austrii komisarze nie byli wyznaczani i odwoływani odgórnie, lecz wybierani spośród szlachty posesjonatów.

Na mocy konstytucji Komisje wojewódzkie i powiatowe w Wielkim Księstwie Litewskim z listopada 1789 r. ustanowiono zasadę obieralności komisarzy na najbliższych sejmikach gospodarskich ${ }^{169}$, pomijając tym samym centralistyczną zasadę zależności osobowej. Przy czym zakładano, że komisarze będę wybierani spośród „dobrze osiadłych”. Ta zasada wykazuje na pewną zbieżność z koncepcją administracji lokalnej Antoniego Popławskiego, który proponował opierać zarząd terytorialny na właścicielach ziemskich posiadających doświadczenie w prowadzeniu własnej gospodarki oraz piastujących urzędy ziemskie ${ }^{170}$.

\footnotetext{
${ }^{167}$ B. Leśnodorski, op. cit., s. 22-23; Z. Kaczmarczyk, B. Leśnodorski, op. cit., s. 258-259; A. Lityński, op. cit., s. 193; J. Bardach, B. Leśnodorski, M. Pietrzak, Historia ustroju i prawa polskiego, Warszawa 1998, s. 225; A.B. Zakrzewski, Wielkie Księstwo Litewskie (XIV-XVIII w.). Prawo, ustrój, społeczeństwo, Warszawa 2013, s. 96-99.

168 M. Weber, Gospodarka i społeczeństwo. Zarys socjologii rozumiejącej, tłum. i wstęp D. Lachowska, Warszawa 2002, s. 164-168.

169 Volumina legum..., t. 9, s. 136.

${ }^{170}$ Ibidem; J. Malec, Polska myśl administracyjna..., s. 59; A. Popławski, op. cit., s. 265-267.
} 
Nie ulega wątpliwości, że punktem odniesienia dla organizacyjnych zbieżności sejmików i komisji porządkowych była tradycja samorządu szlacheckiego. Wiadomo przecież, że zgodnie z postanowieniami sejmu z $1764 \mathrm{r}$. warunkiem czynnego udziału w sejmiku była osiadłość w powiecie, a także niekaralność oraz brak kondemnaty i toczącego się procesu ${ }^{171}$. W konstytucji znajdujemy wzmiankę o udziale „bez obrania” pięciu najwyższych urzędników ziemskiej struktury hierarchicznej ${ }^{172}$, aczkolwiek późniejsze źródła nie wykazują ich czynnego udziału w pracach komisji porządkowych. Nie ma w tym nic dziwnego. Przecież senatorowie, którzy zagajali obrady sejmikowe, rzadko uczestniczyli w sejmikach ${ }^{173}$. Wreszcie do tradycji samorządowej należy odnieść nie tylko obieranie komisarzy na sejmikach, ale także rozliczanie z działalności przed sejmikami.

W gestii samorządu pozostawały niektóre sprawy lokalne, które - jak można sądzić - nie stanowiły obszaru ingerencji władz centralnych. Zgodnie z treścią konstytucji komisje porządkowe były zobowiązane znaleźć w porozumieniu $\mathrm{z}$ sejmikami gospodarskimi środki na naprawę dróg ${ }^{174}$.

Wyżej przytoczone przykłady pozwalają na wysunięcie tezy o powierzeniu instytucjom samorządu szlacheckiego realizacji zadań z zakresu administracji na szczeblu lokalnym ${ }^{175}$, co wskazywałoby na odegranie przez tradycję samorządu szlacheckiego roli spoiwa łączącego wzory dawnych urządzeń samorządowych $\mathrm{z}$ dążeniem do usprawnienia zarządu w terenie.

Analiza treści konstytucji sejmowej z listopada 1789 r. świadczy z kolei o zobowiązaniu komisji cywilno-wojskowych do porozumiewania się i konsultowania swoich decyzji z organami zarządu centralnego, np. przedkładania raportów Komisji Wojskowej lub donoszenia „uwag względem edukacji krajowej” do Komisji Edukacyjnej ${ }^{176}$.

Dążąc do uregulowania stosunków administracyjnych, Komisja Policji w wydanym 12 lipca 1791 r. uniwersale sugerowała, by komisje porządkowe „względem Komisjów Rządowych magistraturami pośredniczemi ulegać wyższym zleceniom obowiązanemu”. Ponadto komisje w terenie ze względu na brak opracowanych „prawideł szczególnych” były zobligowane do poddania się do „prawideł ogólnych prawa”'177.

\footnotetext{
${ }^{171}$ A.B. Zakrzewski, Sejmiki Wielkiego Księstwa Litewskiego..., s. 42, 49.

172 Volumina legum..., t. 9, s. 137.

173 A.B. Zakrzewski, Sejmiki Wielkiego Księstwa Litewskiego..., s. 211.

174 „Co się zaś tyczy traktów ku wygodzie własnego województwa czy powiatu służących, komisja wojewódzka za zniesieniem się na sejmikach gospodarskich z obywatelami skutecznie do ulepszenia onych środki obmyśli, obmyślone do skutku przyprowadzić ma”, Komisje wojewódzkie i powiatowe w Wielkim Księstwie Litewskim..., s. 141.

175 E. Rostworowski, Ostatni król Rzeczypospolitej..., s. 172.

176 Volumina legum..., t. 9, s. 137-142.

${ }^{177}$ Komisja Policji Obojga Narodów. Uniwersał Komisji Policji Obojga Narodów, obwieszczający Komisje Porzadkowe Cywilno-Wojskowe w Koronie i w Wielkim Księstwie Litewskim, 12 VII 1791, druk ulotny (AGAD, tzw. ML, IX 27, k. 322; AGAD, Archiwum Królestwa Polskiego 171, k. 400).
} 
Tymczasem zdaniem komisarzy rolę tych „prawideł” miały odegrać konstytucje sejmowe. Na przykład w 1791 r. oszmiańscy komisarze komunikowali Komisji Policji, że zakres ich uprawnień, działalności oraz „egzekucji dekretów” ujęto w konstytucji sejmowej z końca 1789 r. ${ }^{178}$

Tadeusz Srogosz polemizował z tezą Huberta Izdebskiego o oparciu komisji porządkowych „na zasadzie pełnego samorządu”, twierdząc o ich „silnym uzależnieniu od władz centralnych"179. Wyżej przedstawiony układ stosunków administracyjnych nie wykazuje dokładnego określenia zależności administracji lokalnej od komisji rządowych, co raczej wskazuje na ich współdziałanie ${ }^{180}$ (wysyłanie raportów, donoszenie, powiadamianie komisji centralnych). Świadczy poza tym o toczącym się procesie kształtowania się norm prawa administracyjnego ${ }^{181}$ oraz związaniu działalności komisji przepisami prawa, co należy uznać za krok poczyniony w kierunku rozwoju nowoczesnej administracji publicznej oraz stworzenia prawnoustrojowych podstaw dla działania nowożytnego państwa.

Jak wykazują badania działalności komisji w latach 1789-1792, swoją strukturą organizacyjną komisje porządkowe bardziej przypominały zmodyfikowany model, w którym kontynuacja tradycyjnych urządzeń ustrojowych Rzeczypospolitej, przede wszystkim samorządności szlacheckiej, łączyła się z cechami nowożytnej organizacji administracji (np. zasadą kolegialności i wprowadzeniem elementów specjalizacji i wynagradzania) ${ }^{182}$.

\section{Uwagi końcowe}

Niniejsze przemyślenia mają charakter propozycji badawczych. Nie zakładają one wyczerpania problemu genezy administracji terenowej w okresie Sejmu Czteroletniego, sygnalizują raczej złożony charakter jej powstania. Aukcja wojska oraz związane z nią poważne wyzwania budżetowe skutkowały poszukiwaniem efektywnych sposobów realizacji bieżącej polityki państwa. Dlatego myślą przewodnią konstytucji z listopada 1789 r. było wprowadzenie skutecznych narzędzi realizacji zadań wojskowo-skarbowych. Komisje porządkowe cywilno-wojskowe miały więc gwarantować zaspokojenie palących potrzeb bieżących, na co wskazują utylitarne treści konstytucji, wzbogacone swoistym interpretowaniem wątków założeń ówczesnej myśli ustrojowo-administracyjnej.

\footnotetext{
178 AGAD, Archiwum Królestwa Polskiego 149, k. 302.

179 T. Srogosz, Kształtowanie się nowożytnych lokalnych organów administracyjno-samorządowych..., s. $10-11$.

${ }^{180}$ A. Zahorski, op. cit., s. 65-66; J. Malec, Polska myśl administracyjna..., s. 126.

${ }^{181}$ Problem poddania komisji porządkowych ścisłej kontroli centralnych organów resortowych nie znalazł legislacyjnego rozstrzygnięcia w sejmie; A. Zahorski, op. cit., s. 65-66, 147-148; J. Malec, Narodziny polskiego prawa administracyjnego..., s. 99-111.

182 Ю. Гардзееў, op. cit., s. 41-49, 70.
} 
Niniejsza teza wymaga weryfikacji, sygnalizując konieczność zapoznania się z materiałami Komisji Skarbowej oraz Komisji Wojskowej.

Przy ocenie początków funkcjonowania komisji porządkowych nasuwa się pytanie, czy w analizowanym przypadku należy uwzględniać jedynie czynnik rozwiązań prawodawczych? Przecież myśl legislacyjna była konfrontowana z rzeczywistością, posłowie zaś jako przedstawiciele poszczególnych regionów byli związani sejmikowymi instrukcjami. Daleki od euforycznego traktowania poczynań szlachty Emanuel Rostworowski był zdania, że pomimo swego konserwatyzmu szlachta prowincjonalna postulowała „projekty zorganizowania prowincjonalnej administracji”, dążąc do zreformowania organów samorządowych ${ }^{183}$.

Z tych względów procesu legislacyjnego nie można oddzielić od praktyki życia wspólnot lokalnych oraz doświadczeń szlacheckiej samorządności. Toteż w tym miejscu nie sposób nie zgodzić się z wysuniętą przez Michała Zwierzykowskiego tezą, że komisje porządkowe ani nie stanowiły wyłącznego dzieła sejmu, ani nie były teoretycznym projektem epoki stanisławowskiej ${ }^{184}$. Poza tym - co trzeba podkreślić - rozpatrywanego problemu nie sposób postrzegać, absolutyzując rolę jednego z czynników (próby odgórnych reform lub inicjatywy wspólnot lokalnych). $\mathrm{W}$ związku z powyższym $\mathrm{w}$ świetle przytoczonych materiałów geneza komisji nie wydaje się tak jednoznaczna.

Swoją strukturą organizacyjną komisje porządkowe w znacznym stopniu nawiązywały do rozwiązań rodzimych ${ }^{185}$, co wskazywałoby na konieczność zajęcia się ewolucją egzekutywy samorządu szlacheckiego w XVIII w. ${ }^{186}$ Można zatem przyjąć konieczność zobrazowania czynników, które mogłyby ujawniać się w oddolnej inicjatywie oraz postulatach społeczności lokalnych ${ }^{187}$. Tezę tę można skonfrontować $\mathrm{z}$ aktami sejmików z lat 1788-1789, zawartością pamiętników oraz publicystyką ${ }^{188}$. Kolejnym przedmiotem wnikliwych studiów może być kondycja intelektualna szlachty, jej światopogląd, sposób myślenia, a także inne determinanty, np. podróże, kontakty osobiste, odbyta nauka oraz zainteresowania

${ }^{183}$ E. Rostworowski, Sprawa aukcji wojska..., s. 239.

${ }^{184}$ M. Zwierzykowski, Etapy ewolucji sejmikowej administracji $i$ sadownictwa skarbowego XVI-XVIII wieku. Od partykularnych instytucji do samorząu terytorialnego doby stanisławowskiej, w: Podstawy materialne państwa. Zagadnienia prawo-historyczne, red. D. Bogacz, M. Tkaczuk, Szczecin 2006, s. 64, 70.

185 J. Malec, Polska myśl administracyjna..., s. 111-112.

${ }^{186}$ Акты Виленской археографической комиссии, t. 4: Акты Брестского гродского суда XVI-XVIII вв., Вильна 1870, s. 346-348, 426-429, 440-444, 446-449; t. 7: Акты Гродненского гродского суда, Вильно 1874, s. 214-216, 225-227, 300-303; M. Zwierzykowski, Etapy ewolucji..., s. 68.

187 Zob. stwierdzenie W. Kriegseisena o obszarze zainteresowania sejmików: „Najpierw codzienność - sprawy gospodarcze, samorządowe, administracyjne, skarbowość, porządek i bezpieczeństwo publiczne, a dopiero potem była wielka polityka”; idem, op. cit., s. 98.

188 E. Rostworowski, Sprawa aukcji wojska..., s. 228-233. 
czytelnicze ${ }^{189}$. W tym miejscu trzeba podkreślić fragmentaryczność bazy źródłowej, komplikującą wyjaśnienie zaistniałych wówczas uwarunkowań oraz uzyskanie miarodajnego i udokumentowanego obrazu epoki.

Jest oczywiste, że ze względu na zakreślone ramy tematyczne prezentowane rozważania nie zakładają wyczerpania problemu i uzyskania odpowiedzi na wszystkie możliwe, nurtujące naukę pytania.

\section{Streszczenie}

Prezentowany artykuł przybliża genezę administracji lokalnej w Wielkim Księstwie Litewskim i jest przedstawieniem propozycji badawczych. Zgromadzony materiał sygnalizuje złożony charakter uwarunkowań procesu jej kształtowania. Aukcja wojska oraz związane z nią poważne wyzwania budżetowe wymusiły poszukiwania skutecznych sposobów realizacji bieżącej polityki państwa.

$\mathrm{Na}$ mocy konstytucji z listopada 1789 r. wprowadzono komisje porządkowe cywilno-wojskowe.

Tymczasem, jak wskazują wyniki niniejszego rekonesansu badawczego, inicjatywy legislacyjnej nie można oddzielić od praktyki życia wspólnot lokalnych oraz doświadczeń szlacheckiej samorządności. Poparciem tej tezy są powstałe w 1789 r. komisje furażowe oraz komisje powiatowe, będące prototypami komisji cywilno-wojskowych.

Swoją strukturą organizacyjną komisje porządkowe przypominały model łączący rozwiązania rodzimych urządzeń ustrojowych z cechami nowożytnej organizacji administracji (np. zasadą kolegialności i biurokratyzmu, wprowadzeniem elementów specjalizacji i wynagrodzenia).

\section{On the Genesis of Local Administration in the Grand Duchy of Lithuania: Remarks and Proposals Summary}

The present article goes into the problem of genesis of the local administration in the Grand Duchy of Lithuania in 1789. It has the character of research postulates. The archival sources make it possible to present the complexity of the process of its establishment. The increased number of troops caused serious strains on the state budget and this led to a search for effective ways of implementing the current state policy. The structures of civil-military commissions of order resembled the model combining a native system of governmental authorities with some features of modern administration.

In the Grand Duchy of Lithuania civil-military commissions of order were established by the decision of the Sejm in November of 1789.

However, as demonstrated by the research results, a legislative initiative cannot be separated from the realities of life of local communities and traditions of regional self-government. The establishment of forage commissions and district (powiat) commissions confirms this thesis.

The organizational structure of civil-military commissions resembles the model combining a native system of governmental authorities with some features of modern administration (collegiality principle, bureaucracy, specialization and remuneration).

${ }^{189}$ Należy podkreślić, że zakreślone ramy rozważań nie pozwalają na szczegółowe omówienie tych zagadnień. 


\section{Bibliografia}

\section{Źródła publikowane}

Archiwum tajne Augusta II czyli zbiór aktów urzędowych z czasów panowania tego monarchy, Wrocław 1843.

Diariusz Sejmu Czteroletniego (sesje 1-71), z drukowanego wydania Jana Pawła Łuszczewskiego, Dyaryusz seymu ordynaryinego pod zwiazkiem Konfederacyi Generalney oboyga narodow $w$ Warszawie rozpoczętego roku 1788, Warszawa, Druk. Nadworna J. K. Mci i [...] Kommis. Ed. Narod. 1790, t. 1, cz. 1-2; t. 2, cz. 1-2, http://www.wbc.poznan.pl/Content/32987/45.html (dostęp: 8 II 2015).

Diariusz Sejmu Czteroletniego (sesje 98-198 i 327), z rękopisu przechowywanego w AGAD (w zbiorze Archiwum Sejmu Czteroletniego, rozproszony w różnych tomach) autorstwa Jana Pawła Łuszczewskiego, Antoniego Siarczyńskiego i in., http://www.wbc.poznan.pl/Content/32995/116.html (dostęp: 8 II 2015).

Dyaryusz Seymu Ordynaryinego Pod Związkiem Konfederacyi Generalney Oboyga Narodow w Warszawie Rozpoczętego Roku Pańskiego 1788, t. 1, cz. 1-2, Warszawa 1790.

Garczyński S., Anatomia Rzeczypospolitej Polskiej synom ojczyzny ku przestrodze i poprawie tego, co $z$ kluby wypadło, mianowicie o sposobach zamnożenia Polskę ludem pospolitym, konserwowania dziatwy wiejskiej, przez niedostatek $i$ niewygody marnie ginacej, $i$ wprowadzenia handlów i manufaktur zagranicznych, Berlin 1742.

Kołłątaj H., Do Stanisława Małachowskiego referendarza koronnego, marszałka sejmowego i konfederacji generalnej Anonima listów kilka, cz. 2, [b.m.w.] 1788.

Komisja Policji Obojga Narodów. Uniwersał Komisji Policji Obojga Narodów, obwieszczajacy Komisje Porzadkowe Cywilno-Wojskowe w Koronie i w Wielkim Księstwie Litewskim, 12 VII 1791, druk ulotny.

Komisje wojewódzkie i powiatowe w Wielkim Księstwie Litewskim, w: Volumina legum, t. 9, Kraków 1889 , s. $136-158$.

La Mare de N., Traité de la police, où l'on trouvera l'histoire de son établissement, les fonctions et les prérogatives de ses magistrats; toutes les loix et tous les réglemens qui la concernent, t. 1-4, Paris $1705-1738$.

Lengnich G., Ius publicum Regni Poloniae, t. 1-2, Gedani 1765-1766.

Leszczyński S., Głos wolny wolność ubezpieczający, Kraków 1858.

Materiały do dziejów Sejmu Czteroletniego, t. 2, wyd. i oprac. J. Woliński, J. Michalski, E. Rostworowski, Wrocław 1959.

Mounier J.-J., Considérations sur les gouvernements, et principalement sur celui qui convient à la France, Versailles 1789.

Nax F., Uwagi nad uwagami, czyli obserwacje nad ksiażka pod tytułem: Uwagi nad życiem Jana Zamoyskiego kanclerza i hetmana wielkiego koronnego, Warszawa 1789.

Niemcewicz J.U., Pamiętniki czasów moich, t. 1, oprac. J. Dihm, [Warszawa] 1957.

Ofiara na pierwsze potrzeby wojska W. X. Litt., w: Volumina legum, t. 9, Kraków 1889, s. 65-66.

Ofiara od nas Króla, w: Volumina legum, t. 9, Kraków 1889, s. 72.

Ofiara wieczysta prowincjów obojga narodów na powiększenie sił krajowych, w: Volumina legum, t. 9, Kraków 1889, s. 73-74.

Opatrzenie bezpieczeństw województw ruskich, w: Volumina legum, t. 9, Kraków 1889, s. 71.

Ossowski M., Uwagi nad projektem o pomnożeniu dochodów publicznych, [Warszawa 1789].

Paine T., Recueil des divers écrits de Thomas Paine [...] sur la politique et la législation, faisant suite aux autres ouvrages du même auteur, intitulés: Les droits de l'homme et Le sens commun, tłum. $\mathrm{z}$ ang., Paris, F. Buisson 1793.

Pamiętniki z ośmnastego wieku, t. 7, Poznań 1867. 
Pellissery R.-A. de, L'Administration politique de Colbert: ouvrage qui par son érudition, ses principes économiques, calculs politiques \& c. peut servir de repertoire universel des connoissances nécessaires à des administrateurs, Amsterdam-Lepzig 1776.

Popławski A., Zbiór niektórych materii politycznych, Warszawa 1774.

Puszet J., O uszcześliwieniu narodów, Warszawa 1788.

Seryarz projektów do prawa i innych różnych pism, uwagi, myśli patryotycznych, żadań, woiewództw ziem i powiatów pomiędzy seymem a seymem od senatorów, posłów y gorliwych patryotów formowanych roku pierwszego 1785, t. 1-2, [b.m.w.] 1785.

Seweryna Rzewuskiego hetmana polnego koronnego O sukcesyi tronu w Polszcze rzecz krótka, Amsterdam 1789; [Warszawa] 1789.

Skrzetuski W., Prawo polityczne narodu polskiego, t. 1-2, Warszawa 1782-1784.

Sposób wynalezienia ofiary $z$ dóbr ziemskich $i$ duchownych $w$ Koronie $i w$ Wielkim Księstwie Litewskim, w: Volumina legum, t. 9, Kraków 1889, s. 77-95.

Stroynowski H., Nauka prawa przyrodzonego, politycznego, ekonomiki polityczney, y prawa narodów, Wilno 1785.

Wielhorski M., O przywróceniu dawnego rzadu wedtug pierwiastkowych Rzeczypospolitej ustaw, [b.m.w.] 1775.

Województw, ziem i powiatów do swoich posłów sejmujacych roku 1788 i 1789, w: Zbiór mów i pism niektórych w czasie sejmu stanów skonfederowanych roku 1788, t. 1, Wilno [b.d.w.].

Wolff Ch., Jus Naturae, Methodo, Scientifica Pertractatum, t. 1-8, Francofurti-Lipsiae 1740-1748.

Zbiór mów i pism niektórych w czasie sejmu stanów skonfederowanych roku 1788, t. 1, Wilno [b.d.w.], s. 114.

Акты Виленской археографической комиссии, t. 4: Акты Брестского гродского суда XVI-XVIII вв., Вильна 1870; t. 7: Акть Гродненского гродского суда, Вильно 1874; t. 38: Инвентари староств, имений, фольварков и деревень XVIII века, Вильно 1914.

Книжное собрание рода Хрептовичей [Электронный ресурс] Нац. б-ка Украины им. В.И. Вернадского, Нац. б-ка Беларуси, Нац. комис. Респ. Беларусь по делам ЮНЕСКО, оprac. Л.Г. Кирюхина, Л.А. Дубровина, red. Л.Г. Кирюхина, Т.И. Рощина, Минск 2009.

\section{Opracowania}

Baranowski I., Komisje porządkowe (1765-1788), „Rozprawy Akademii Umiejętności Wydziału Historyczno-Filozoficznego", s. II, t. 24, 1907, s. 107-150.

Bardach J., Leśnodorski B., Pietrzak M., Historia ustroju i prawa polskiego, Warszawa 1998.

Biblioteka Stanisława Augusta na zamku warszawskim, oprac. J. Rudnicka, Wrocław 1988.

Drozdowski M., Podstawy finansowe działalności państwowej w Polsce w 1764-1793. Działalność budżetowa Sejmu Rzeczypospolitej w czasach panowania Stanisława Augusta Poniatowskiego, Warszawa-Poznań 1975.

Glemža L., Lietuvos Didžiosios Kunigaikštystès miestų sajūdis 1789-1792 metais, Kaunas 2010.

Goliński Z., Biblioteki i czytelnictwo, w: Słownik literatury polskiego Oświecenia, red. T. Kostkiewiczowa, Wrocław 1996, s. 31-40.

Gordziejew J., Komisje Porzadkowe Cywilno-Wojskowe w Wielkim Księstwie Litewskim w okresie Sejmu Czteroletniego (1789-1792), Kraków 2010.

Grześkowiak-Krwawicz A., Publicystyka stanisławowska o modelu rządów monarchii francuskiej, Wrocław 1990.

Jędrzejewski P., Akta Komisji Porządkowych Cywilno-Wojskowych, „Krakowski Rocznik Archiwalny" 9, 2013, s. 129-157. 
Jędrzejewski P., Komisje Porządkowe Cywilno-Wojskowe województwa krakowskiego w dobie Sejmu Wielkiego (1790-1792), Kraków 2016, Uniwersytet Pedagogiczny, mps pracy doktorskiej napisanej pod kier. prof. dr. hab. Franciszka Leśniaka.

Jurgaitis R., Funkcjonowanie sejmiku wileńskiego w latach 1717-1795. Między szlacheckim parlamentaryzmem a samorządem, w: Praktyka życia publicznego w Rzeczypospolitej Obojga Narodów w XVI-XVIII wieku. Materiały pokonferencyjne XVIII Komisji Lituanistycznej przy KNH PAN, red. U. Augustyniak, A.B. Zakrzewski, Warszawa 2010, s. 46-51.

Kaczmarczyk Z., Leśnodorski B., Historia państwa i prawa Polski, red. J. Bardach, t. 2: Od połowy XV wieku do r. 1795, wyd. 4, Warszawa 1971.

Kalinka W., Sejm Czteroletni, t. 1, cz. 1-2, wyd. 4, Kraków 1895.

Kalinka W., Sejm Czteroletni, t. 1, Warszawa 1991.

Köhler P., Biblioteka naukowa Józefa Jundziłła (1794-1877), „Kwartalnik Historii Nauki i Techniki” 42, 1997, nr 3-4, s. 63-84.

Konieczna D., Ustrój i funkcjonowanie sejmiku brzesko-litewskiego w latach 1565-1763, Warszawa 2013.

Korzon T., Komisje porządkowe Cywilno-Wojskowe wojewódzkie i powiatowe w latach 1790-1792, „Ateneum" 7, t. 1, z. 1, 1882, s. 427-455.

Korzon T., Wewnętrzne dzieje Polski za Stanisława Augusta (1764-1794), t. 1-3, 5, Kraków-Warszawa 1897.

Kowkiel L., Prywatne księgozbiory na Grodzieńszczyźnie w pierwszej połowie XIX wieku, Kraków 2005.

Kriegseisen W., Sejmiki Rzeczypospolitej szlacheckiej w XVII i XVIII wieku, Warszawa 1991.

Libera Z., Sejm Czteroletni w oczach pamiętnikarzy, w: Sejm Czteroletni i jego tradycje, red. J. Kowecki, Warszawa 1991, s. 177-188.

Lipiński E., Studia nad historią polskiej myśli ekonomicznej, Warszawa 1956.

Lityński A., Sejmiki ziemskie 1764-1793. Dzieje reformy, Katowice 1988.

Łaszewski R., Sejm polski w latach 1764-1793, Warszawa-Poznań 1973.

Malec J., O recenzji Wacława Uruszczaka uwag kilka, „Czasopismo Prawno-Historyczne” 41, 1989, z. 1, s. 209-215.

Malec J., Polska myśl administracyjna XVIII wieku, Kraków 2008.

Malec J., Studia z dziejów administracji nowożytnej, Kraków 2003.

Michalski J., Zmierzch prokonsulatu Stackelberga, w: Sejm Czteroletni i jego tradycje, red. J. Kowecki, Warszawa 1991, s. 18-49.

Paszkiewicz U., Wybrane problemy dokumentacji zbiorów bibliotecznych na wschodnich ziemiach Rzeczypospolitej do 1939 roku, „Roczniki Biblioteczne” 45, 2001, s. 55-89.

Paszkiewicz U., Z warsztatu badań proweniencyjnych. Wybrane znaki własnościowe księgozbiorów prywatnych na wschodnich ziemiach Rzeczypospolitej, „Roczniki Biblioteczne” 48, 2004 [2005], s. 107-126.

Rachuba A., Wielkie Księstwo Litewskie w systemie parlamentarnym Rzeczypospolitej w latach 1569-1763, Warszawa 2002.

Radaman A., Samorząd sejmikowy w powiatach województwa nowogródzkiego Wielkiego Księstwa Litewskiego w latach 1565-1632, w: Praktyka życia publicznego w Rzeczypospolitej Obojga Narodów w XVI-XVIII wieku. Materiały pokonferencyjne XVIII Komisji Lituanistycznej przy KNH $P A N$, red. U. Augustyniak, A.B. Zakrzewski, Warszawa 2010, s. 55-103.

Ratajczyk L., Przyczynek do sprawy werbunku i poboru rekrutów na ziemiach polskich w XVIII wieku, „Studia i Materiały do Historii Wojskowości” 15, cz. 1, 1969, s. 61-72.

Ratajczyk L., Wojsko i obronność Rzeczypospolitej 1788-1792, Warszawa 1975.

Rolnik D., Portret szlachty czasów stanisławowskich, epoki kryzysu, odrodzenia i upadku Rzeczypospolitej w pamiętnikach polskich, wyd. 2, Katowice 2011.

Rostworowski E., Ostatni król Rzeczypospolitej. Geneza i upadek Konstytucji 3 Maja, Warszawa 1966. 
Rostworowski E., Sprawa aukcji wojska na tle sytuacji politycznej przed Sejmem, Warszawa 1957.

Rudnicka J., Biblioteka Ignacego Potockiego, Wrocław 1953.

Rudnicka J., Czytelnicy w bibliotece warszawskiej marszałka Lubomirskiego, „Przegląd Biblioteczny” 1958 , nr 2, s. 207-213.

Seidler G.L., W nurcie Oświecenia, Lublin 2002.

Srogosz T., Kształtowanie się nowożytnych lokalnych organów administracyjno-samorzadowych na ukrainskich terenach Rzeczypospolitej w drugiej połowie XVIII wieku, „Південний архів” 20, 2005, s. 8-11.

Srogosz T., Między unifikacją a dualizmem w systemie władz policyjnych u schyłku pierwszej Rzeczypospolitej, w: Spory o państwo $w$ dobie nowożytnej. Między racja stanu a partykularyzmem, red. Z. Anusik, Łódź 2007, s. 243-254.

Srogosz T., Nowożytne lokalne organy administracyjno-samorzadowe na ukrainskich terenach Rzeczypospolitej w okresie panowania Stanisława Augusta Poniatowskiego, w: Urzędy państwowe, organy samorzadowe i kościelne oraz ich kancelarie, red. H. Gmiterek, J. Łosowski, Kraków 2010, s. 197-210. Stankiewicz W., Historia myśli ekonomicznej, Warszawa 1983.

Starzeński M., Na schyłku dni Rzeczypospolitej (1757-1795), wyd. H. Mościcki, Warszawa 1914.

Szczygielski W., Debata parlamentarna nad wyłonieniem składu Komisji Wojskowej w grudniu 1788 r., „Przegląd Nauk Historycznych” 10, 2011, nr 1, s. 71-115.

Šmigelskytė-Stukienė R., Brusokas E., Glemža L., Jurgaitis R., Rakutis V., Modernios administracijos tapsmas Lietuvoje. Valstybès institucijų raida 1764-1794 metais, Vilnius 2014.

Urzędnicy centralni i dostojnicy Wielkiego Księstwa Litewskiego XIV-XVIII wieku, oprac. H. Lulewicz, A. Rachuba, Kórnik 1994.

Weber M., Gospodarka i społeczeństwo. Zarys socjologii rozumiejącej, tłum. i wstęp D. Lachowska, Warszawa 2002.

Wojakowski J., Ksiegozbiory Eustachego Kajetana Sapiehy (1797-1860) i Wacława Seweryna Rzewuskiego (1785-1831), Warszawa 1996.

Zahorski A., Centralne instytucje policyjne w Polsce w dobie rozbiorów, Warszawa 1959.

Zakrzewski A.B., Sejmiki Wielkiego Księstwa Litewskiego XVI-XVIII w. Ustrój i funkcjonowanie sejmik trocki, Warszawa 2000.

Zakrzewski A.B., Wielkie Księstwo Litewskie (XIV-XVIII w.). Prawo, ustrój, społeczeństwo, Warszawa 2013.

Zwierzykowski M., Etapy ewolucji sejmikowej administracji i sądownictwa skarbowego XVI-XVIII wieku. Od partykularnych instytucji do samorzadu terytorialnego doby stanisławowskiej, w: Podstawy materialne państwa. Zagadnienia prawo-historyczne, red. D. Bogacz, M. Tkaczuk, Szczecin 2006, s. 63-71.

Zwierzykowski M., Funkcjonowanie samorządu sejmikowego województw poznańskiego i kaliskiego od XVI do XVIII wieku, w: Sejmik wielkopolski, red. A. Kamieński, Jarocin-Szczecin 2008, s. $19-33$.

Гардзееў Ю., Цывільна-вайсковыя парадкавыя камісіі у Вялікім Княстве Літоускім у часы Чатьрохгадовага сойма (1789-1792), Смаленск 2014.

Куль-Сяльверстава С., Палітыка, культура, асоба. Нарысы па гісторыі культуры Беларусі, Гродна 2012, http://pawet.net/library/history/bel_history/kul/10/Палітыка._Культура._Асоба.. html\#_Toc3496758 (dostęp: 8 II 2015).

Мацук А., Соймікі Полаикага ваяводства у панаванне Аўгуста III, „Вестник Полоцкого Государственного Университета. Серия А” 2011, nr 9, s. 32-39.

Jerzy Gordziejew - dr hab., adiunkt w Instytucie Rosji i Europy Wschodniej Uniwersytetu Jagiellońskiego. Jego zainteresowania badawcze obejmują dzieje społeczno-gospodarcze i kulturalne miast Wielkiego Księstwa Litewskiego, modernizacji administracji lokalnej w okresie Sejmu Czteroletniego. E-mail: hardziejeu@gmail.com 